\title{
CARTA QUE UN AMIGO ESCRIBE A OTRO: RELACIÓN POÉTICA INÉDITA DE LA DEDICACIÓN DE LA IGLESIA JESUÍTICA DE SAN PABLO (LIMA, 1638)
}

El 30 de julio de 1638 fue un día de fastos y alboroto en las calles de Lima. Tras años de labores de construcción, tuvo lugar un gran festejo acompañado de procesiones para celebrar la víspera de la dedicación de la nueva iglesia jesuítica de San Pablo, que se hizo coincidir con el día de san Ignacio. La Compañía de Jesús se había establecido en el virreinato del Perú en 1568, y en poco menos de un siglo fundó cuatro iglesias en su capital: San Pablo (hoy San Pedro), Santiago del Cercado (1570, reedificada en 1601), San Antonio Abad o Noviciado (ca. 1612) y Nuestra Señora de los Desamparados $(1658)^{1}$. De todas ellas, la de San Pablo era la más monumental y la que tenía una mayor carga simbólica, porque se asumía que se había construido siguiendo los planos de la iglesia del Gesù de Roma, como señalaba el padre Nicolás Durán Mastrilli en la carta anua de 1639, donde decía que el templo limeño "se aventaja a lo que hay por acá, porque es un modelo pequeño de la casa profesa de Roma, cuya planta traje yo"2. Sin embargo, lo cierto es que el edificio se inspiraba sobre todo en la Iglesia de la Compañía de Quito (abierta al culto en 1613), cuyo plano también había sido traído desde

1 Rubén Vargas Ugarte, Los jesuitas del Perú y el arte, Librería e Imprenta Gil, Lima, 1963, pp. 14-56 y 76-85; Luisa Elena Alcalá (ed.), Fundaciones jesuíticas en Iberoamérica, Iberdrola-El Viso, Madrid, 2002, pp. 90-116.

${ }^{2}$ Carta anua, Lima, 30 de mayo de 1639, Archivum Romanum Societatis Iesu, Peru 15, ff. $127^{\mathrm{r}}-155^{\mathrm{v}}$ (f. $130^{\mathrm{v}}$ ). La carta aparece reproducida parcialmente en EnriQue Torres SAldamando, "El colegio máximo de San Pablo. (Apuntes para la historia de la Compañía de Jesús en el Perú)", Revista Peruana, 4 (1880), pp. 468-470; y R. VARGas UGarTe, op. cit., pp. 23-24. 
Roma por Durán Mastrilli ${ }^{3}$. La idea de que la mayoría de las iglesias jesuíticas en el Nuevo Mundo era una réplica más o menos directa del Gesù se convirtió en un lugar común de fuerte calado ideológico, y el templo de San Pablo no supuso una excepción.

La iglesia y colegio de San Pablo era, en realidad, el edifico fundacional de los jesuitas en $\mathrm{Lima}^{4}$. Su solar se hallaba a pocas manzanas de la plaza Mayor, y allí se establecieron los padres de la Compañía desde 1568, edificando primero un templo que fue reemplazado por otro en 1574, y finalmente por el tercero, que se construyó entre 1624 y 1638 . La dedicación de este último representaba, pues, la consagración de la presencia y el poderío de los jesuitas en el Perú, reflejada en la imponente y costosa estructura de la obra, como recuerda Diego de Medrano, continuador del Diario de Juan Antonio Suardo: "es muy suntuosa y fuerte para los temblores, y bien trazada, que ha costado de hacer su obra más de medio millón" ${ }^{5}$. Ello explica por qué las ceremonias y procesiones que acompañaron su inauguración se vieron cargadas de tanta expectación e involucraron a las varias capas sociales, desde las más privilegiadas a las más populares. Los festejos comenzaron ya el 29 de julio, con la visita a San Pablo del obispo de Chile, el agustino Gaspar de Villarroel, quien bautizó su campana mayor con el nombre de San Agustín. Al día siguiente, tuvo lugar la aparatosa procesión:

En 30 por la tarde, fue su excelencia con los señores de la Real Audiencia a la iglesia vieja de la Compañía de Jesús, desde donde estaba prevenida la procesión que fue a la santa iglesia catedral desta ciudad, acompañada del deán y Cabildo y regimiento della,

3 Gauvin Alexander Bailey, "Just Like the Gesù: Sebastiano Serlio, Giacomo Vignola, and the Jesuit architecture in South America”, AHSI, 70 (2001), p. 247; Elena Alcalá, op. cit., p. 194.

4 EnriQue Torres Saldamando, art. cit.; Rubén Vargas Ugarte, Historia de la Compañía de Jesús en el Perú, Imprenta de Aldecoa, Burgos, 1963-1965, t. 1, pp. 43-54; Luis Martín, The intellectual conquest of Peru: The Jesuit College of San Pablo, 1568-1767, Fordham University Press, New York, 1968.

${ }^{5}$ Juan Antonio Suardo, Diario de Lima (1629-1639), ed. Rubén Vargas Ugarte, Lumen, Lima, 1936, t. 2, p. 188. El Virrey le encargó al clérigo Juan Antonio Suardo que llevara a cabo un diario de la ciudad de Lima, tarea que realizó desde 1629 a 1637. Esta labor fue continuada por Medrano, cuya identidad queda todavía por aclarar; cf. Guillermo Lohmann Villena, "Algunas noticias biográficas sobre Diego de Medrano continuador del Diario de Lima (1637-1639)", Cuadernos de Información Bibliográfica, Lima, 3/4 (1958), pp. 40-41. La parte del diario que le corresponde va del primero de junio de 1637 al treinta de mayo de 1639 (Diario, t. 1, pp. vi-vii). 
que llevaban el palio del Santísimo Sacramento con toda la clerecía y parroquias, y desde la dicha santa iglesia fue al convento de San Agustín, pasando por la calle en donde había muy solenes altares y, en medio la iglesia del dicho convento se hizo uno muy grandioso con el patriarca san Ignacio, a quien en la dicha procesión iban alumbrando toda la nación vascongada; y desde el dicho convento de San Agustín se encaminó para la iglesia nueva y trasladar en ella el Santísimo Sacramento, acompañándola todos los santos del Orden de San Agustín, que iban de dos en dos con los de la Compañía de Jesús en sus andas muy bien aderezadas, que parecieron muy bien, y asimismo las comunidades juntas de la Compañía y San Agustín, sin que hubiese fraile de otra religión en toda la dicha procesión. Y, a la noche, hubo muchos y muy grandes fuegos y luminarias por toda la ciudad; y para verlos y pasar la dicha procesión fue la señora virreina y marqués, su hijo, a casa del oidor Merlo de la Fuente, desde donde la vio pasar y los fuegos a la noche, hasta que se fue su excelencia a palacio ${ }^{6}$.

Las celebraciones concluyeron al día siguiente con la fiesta a la dedicación de la nueva iglesia y en honor de san Ignacio, a la que acudieron el virrey, los miembros de la Real Audiencia y de los Cabildos Eclesiástico y Secular, además de contar con el obispo de Chile y la presencia del doctor Bartolomé de Benavides, quien predicó un sermón. De todos estos acontecimientos, que tuvieron lugar entre el 29 y el 31 de julio de 1638, se conservan varios testimonios y relaciones, como las cartas anuas de los jesuitas, el diario de Medrano -que se acaba de citar-y una anónima Relación succinta de la dedicación del famoso templo de San Pablo de la Compañía de Jesús y translación que se hizo del antiguo, incluida en el sermón de Benavides que se publicó en Lima en 16397. En este trabajo, presento y edito un nuevo documento que ofrece más informaciones sobre estos días de pompa y circunstancia, además de sobre la estructura arquitectónica y el interior de la iglesia de San Pablo, que complementan y amplían los datos que habían proporcionado las cartas anuas y la Historia de la fundación de Lima (1639) del padre Bernabé Cobo ${ }^{8}$.

${ }^{6}$ SuARdo, Diario, t. 2, pp. 187-188.

7 Bartolomé de Benavides, Sermón en la dedicación del nuevo y famoso templo de San Pablo de la Compañía de Jesús de Lima, en el día del glorioso patriarca san Ignacio, Jerónimo de Contreras, Lima, 1639, ff. $1^{\mathrm{r}}-3^{\mathrm{r}}$.

8 Bernabé Cobo, Historia de la fundación de Lima, ed. M. González de la Rosa, Imprenta Liberal, Lima, 1882, pp. 270-271. 


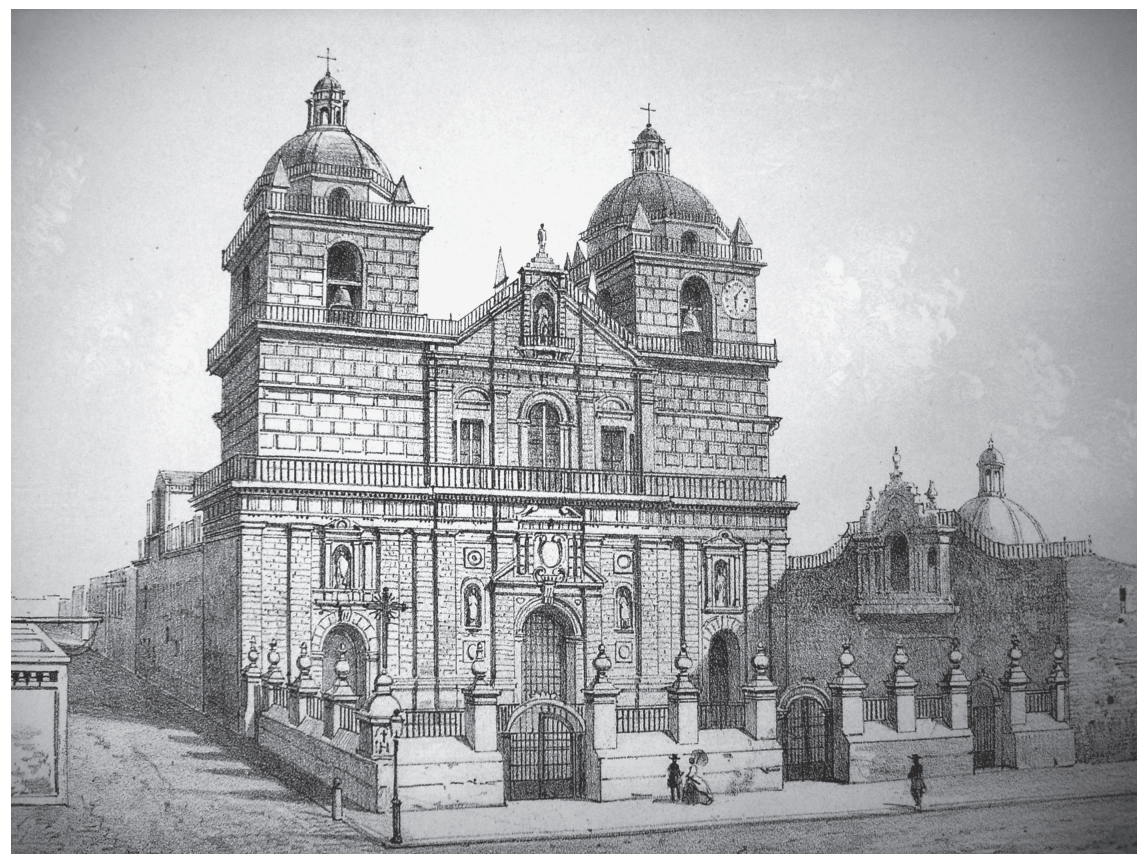

Imagen 1. Iglesia de San Pablo (hoy San Pedro), en Mariano Felipe Paz Soldán, "Atlas geográfico del Perú", Librería de Fermín Didot, París, 1865, lámina XXviI.

La biblioteca de la Hispanic Society of America posee entre sus fondos un manuscrito poético, probablemente autógrafo, donde se contiene una epístola escrita en forma de romance y compuesta el 8 de agosto de 1638. Su título completo es: Carta que un amigo escribe a otro desde Lima a Potosí, en que le hace relación del templo nuevo de la Compañía de Jesús y fiesta a su edificación y a san Ignacio en su día postrero de julio de 1638 años. El texto lleva la signatura B2506, y fue descrito por Antonio Rodríguez-Moñino y María Brey en su Catálogo, donde aparece con el número CCXXXIII ${ }^{9}$. El manuscrito procede de la colección del marqués de Jerez de los Caballeros, quien, en su día, había adquirido

9 Antonio Rodríguez-Moñino y María Brey Mariño, Catálogo de los manuscritos poéticos castellanos existentes en la biblioteca de The Hispanic Society of America, siglos XV, XVI y XVII, Hispanic Society of America, New York, 1965-1966, t. 2, p. 478: "215 mm. 15 folios a dos columnas, numerados a lápiz. Rústica. Letra contemporánea al suceso. A la vuelta del último folio hay esta dirección: "S. ${ }^{\text {or }}$ Cap. ${ }^{\text {an }}$ Baltazar de Amesqueta". El texto va fechado al final en Lima, 8 de agosto de 1638. El autor se llama a sí mismo Menandro. PROCEDENCIA: Marqués de Jerez de los Caballeros. Archer M. Huntington”. 
numerosas obras procedentes de los fondos de José Sancho Rayón y Bartolomé J. Gallardo ${ }^{10}$. Hasta donde se me alcanza, la Carta no ha sido nunca estudiada ni editada, pese a su evidente importancia para el estudio y el conocimiento de la historia, la literatura, el arte y la arquitectura limeña del siglo XVII. El objetivo del presente artículo es dar a conocer este poema, llevando a cabo una edición crítica y anotada del mismo ${ }^{11}$.

\section{Autoría, Fecha y Circunstancia de la CARTA}

Lo único seguro en cuanto a la autoría y fecha de la Carta es lo segundo, pues el poeta afirma al final del texto que lo ha compuesto en Lima el 8 de agosto de 1638 (vv. 1641-1644). El poema no lleva el nombre de su autor, quien se oculta detrás del seudónimo de Menandro (vv. 460, 1649, 1654, 1660). Por lo que nos cuenta, podemos deducir que era un hombre de edad avanzada o, cuando menos, no joven. En el verso 452 dice que es "de adelantados años", e insiste sobre esta idea en más ocasiones (vv. 475 y 479), ofreciendo además un sucinto autorretrato burlesco de su persona, donde se describe a sí mismo como alto, encorvado, mustio y melancólico: "muy torcido de pescuezo, / pensativo, carilacio / y con una elevación / como bulto de retablo" (vv. 481-484). Nos dice también que no es fraile mercedario (vv. 247-248), y por la manera en la que habla de la Compañía como de un grupo ajeno a él -"los de la ilustre familia / del gran patriarca Ignacio" (w. 35-36)- parece que tampoco era jesuita. A su vez, de su elogio de la iglesia de San Pablo es posible deducir que quizás fuera criollo. Al describir la capilla mayor, dice que es "la mejor que se ha labrado / en Europa ni en las Indias" (vv. 94-95), y sustenta su argumento en el testimonio ("testifican") de aquellos que "de allá vienen y que han visto /

10 Ibid., t. 3, pp. 53-106.

11 Deseo expresar todo mi agradecimiento a la Hispanic Society of America, que me ha permitido publicar las imágenes del manuscrito reproducidas en este artículo y, sobre todo, al doctor John O’Neill, bibliotecario de dicha institución, cuya generosidad y amabilidad han facilitado enormemente mi trabajo. Quiero también agradecer su ayuda al personal del Archivo General de Indias (AGI), al doctor Francisco Fernández López, del Archivo Histórico Provincial de Sevilla, a los profesores José Manuel Rico García, Rafael Bonilla Cerezo y Antonio Carreira, y a los lectores anónimos que evaluaron mi artículo. Todos ellos me han aportado informaciones y consejos muy valiosos. 
lo hasta agora edificado / en conventos religiosos" (wv. 97-99). Estos versos podrían sugerir que el poeta nunca había estado en el Viejo Mundo.

La Carta no es solo una relación, sino también y ante todo una epístola en verso que sigue las convenciones del género, intercambiando confidencias y gracias a través del empleo de un estilo mediano y a menudo coloquial ${ }^{12}$. El autor insiste en su supuesta falta de habilidad poética y en su ignorancia (vv. 437438, 449-451, 1515-1528...), afirmando que había escrito algún verso de joven (vv. 505-506), pero "que ha mucho / que este género no masco" (vv. 1555-1556). Todo ello parece obedecer en realidad al empleo del tópico de la falsa modestia y al tono auto-irónico que este suele adoptar en el género epistolar ya desde Horacio. Lo cierto es que el poeta maneja con bastante soltura el octosílabo, pese a que no falten algunos deslices y versos hipermétricos (503, 819 y 1408). A su vez, demuestra conocer bien las convenciones de la epístola poética y escoge el nombre de Fabio, de estampa clasicista, para su interlocutor, quizás en recuerdo a la Epistola moral a Fabio (ca.1612) de Andrés Fernández de Andrada. Menos clara resulta la motivación subyacente tras el empleo del seudónimo de Menandro. Según el poeta, incluso el destinatario de la Carta reaccionará sorprendido ante esta identidad ficticia:
Pienso, Fabio, estrañaréis
de que me firmo Menandro.
La novedad no os admire, que poetas de mi trato me aconsejan que lo haga y su consejo he tomado, y así, de pastor moreno, me he vuelto pastor Menandro (vv. 1653-1660).

El pasaje resulta un tanto enigmático. ¿Es "pastor moreno" un juego onomástico que hace referencia al apellido del poeta? ¿Se trata de una referencia a los personajes tradicionales de los pastores de la lírica folclórica, del romancero o de las composi-

12 Para una puesta al día sobre este género, véase VALEnTín Núñez Rivera, "La humilde sumisión de ornato huye. Epístola y poesía lírica en el Siglo de Oro”, en Los géneros poéticos del Siglo de Oro: centros y periferias, eds. Rodrigo Cacho Casal y Anne Holloway, Tamesis, Woodbridge, 2013, pp. 49-65. 
ciones bucólicas? ¿Es pastor acaso una alusión al hecho de que el autor era un miembro del clero? Es indudable que se trataba de un hombre culto, que poseía información de primera mano sobre la nueva iglesia de San Pablo, de la que da detalles minuciosos, y que se coloca a sí mismo en el centro de la sociedad limeña, como observador privilegiado. Por lo que cuenta en la Carta, se deduce que en las misivas anteriores que Menandro le ha enviado a Fabio también se ha explayado relatándole los pormenores del día a día en la capital del Perú, habiendo "de todo lo subcedido / largas relaciones dado" (vv. 11-12). Pues bien, la persona encargada por el virrey, el conde de Chinchón, de escribir un diario de Lima entre los años 1637 y 1639 fue el ya mentado Diego de Medrano.

Pese a que no sepamos nada acerca de sus inclinaciones poéticas, el papel destacado de Medrano como cronista de lo cotidiano pondría a su alcance una gran variedad de fuentes de información, cuya riqueza queda de manifiesto en la Carta. Por otro lado, el seudónimo Menandro guarda un parecido notable con Medrano, del que es un anagrama casi perfecto. Desde luego, esta atribución es tan solo una conjetura, a la espera del hallazgo de otros documentos que permitan confirmarla o refutarla. Los pocos datos que conocemos sobre Medrano no resultan concluyentes. Lohmann Villena identificó al continuador del Diario de Suardo con un Diego de Medrano que pasó de España al Perú en $1621^{13}$. En la década de 1620 ocupó varios puestos y cargos, como lugarteniente del correo mayor don Diego de Vargas Carvajal, arcabucero y alférez de la compañía de caballería del número de Lima, hasta conseguir ser nombrado contador. Desconocemos la fecha de su nacimiento y de su muerte. Todavía vivía en 1652.

Mucho más sencillo resulta identificar a la persona que se encubre detrás del nombre Fabio, pues el destinatario de la Car$t a$ se indica en el vuelto del último folio: "Señor capitán Baltasar de Amezqueta" (o Amézqueta). El manuscrito aparece plegado como se hacía con las misivas, y debió ser enviado por correo ordinario u otro medio de Lima al Potosí, como aclaran los primeros versos del romance (5-40). En ellos, el poeta Menandro se queja porque Fabio/Amezqueta falta de Lima desde hace un año, y no ha contestado a ninguna de las doce cartas anteriores que le ha enviado al Potosí, donde debía encontrarse por aquel

13 Guillermo Lohmann Villena, art. cit. 
entonces. Baltasar de Amezqueta era originario de San Sebastián, donde había nacido entre 1601 y $1602^{14}$. Al igual que su hermano, Juan de Amezqueta, fue maestre de nao en la Carrera de Indias, además de haber ejercido de maestre de plata ${ }^{15}$. Este era un cargo muy codiciado en la época, pues garantizaba muchos privilegios, sobre todo de tipo económico. Su función principal era la de ocuparse del transporte de plata de América a España y de los trámites que este acarreaba ${ }^{16}$. Su sueldo solía ser bastante limitado, y a menudo no alcanzaba a cubrir los gastos, pero los beneficios mayores les llegaban a través de varias formas más o menos toleradas de fraude, transportando plata y otros bienes no registrados. El Archivo de Indias guarda documentos que dan fe de los frecuentes problemas con la ley que tuvo Baltasar de Amezqueta, quien acabó más de una vez en la cárcel ${ }^{17}$.

14 Para reconstruir la biografía de Amezqueta me he servido de su testamento autógrafo, firmado en Sevilla el 12 de junio de 1647, que se encuentra en el Archivo Histórico Provincial de Sevilla, Sección de Protocolos, 10199, ff. $318^{\mathrm{r}}-321^{\mathrm{v}}$; además de varios pleitos en los que se vio envuelto, conservados en el Archivo General de Indias (AGI). En Contratación, 833, n. 13 dice que "soy vizcaíno originario" (f. 14 ${ }^{\mathrm{r}}$ ); y en una declaración jurada del 25 de enero de 1627 afirma que "es de edad de más de veinte y cinco años" (Contratación, 647A, n. 2, r. 10). Su testamento indica que sus padres fueron el capitán Juan de Amezqueta y doña Mariana de Gabiria, vecinos y naturales de San Sebastián.

15 Su hermano Juan había nacido en San Sebastián, a donde regresó tras años viviendo en Cádiz y comerciando con el Nuevo Mundo. Otorgó testamento en San Sebastián el 2 de octubre de 1643, y murió en la misma ciudad el 25 de enero de 1649 (AGI, Consulados, 1242, ff. 165 ${ }^{\mathrm{v}}-175^{\mathrm{v}}$ ). En su testamento nombra entre sus albaceas a su hermano Baltasar, y declara que este es "residente en la ciudad de Sevilla" (f. $170^{\mathrm{v}}$ ). Véanse los trabajos de José Garmendia, "Los vascos en Sevilla", $A B C$, Sevilla, 9/5/1973, p. 23; y "Los capitanes Juan y Baltasar de Amézqueta”, Boletín de Estudios Históricos sobre San Sebastián, 20 (1986), 383-399.

16 EnRiQueta Vila Vilar, "Los maestres de plata: un resorte de poder en el comercio con Indias", en Entre Puebla de los Ángeles y Sevilla. Estudios americanistas en homenaje al Dr. José Antonio Calderón Quijano, eds. María Justina Sarabia Viejo et al., Escuela de Estudios Hispano-Americanos de Sevilla-CSICUniversidad de Sevilla, Sevilla, 1997, pp. 119-131; Carlos Álvarez Nogal, "Los maestres de plata durante el reinado de Felipe IV. Nombramientos y beneficios", en Ciencia, economía y política en Hispanoamérica colonial, coord. Antonio Gutiérrez Escudero, Escuela de Estudios Hispano-Americanos de Sevilla-CSIC, Sevilla, 2001, pp. 139-159.

17 Por ejemplo, en 1627 (AGI, Contratación, 647A, n. 2, r. 10) y 1633 (AGI, Contratación, 175, n. 1, r. 19). Al respecto, véase también Juan Ricardo Jiménez Gómez, "Actos, contratos y pleitos de la navegación en la Carrera de Indias en el siglo xviı", en La Flota de la Nueva 
Pese a estos percances legales, bastante habituales por otro lado entre los comerciantes y maestres de nao en la Carrera de Indias, Amezqueta tuvo que disfrutar de una posición relativamente privilegiada, con varios contactos tanto en Sevilla como en América. Los maestres de plata casi siempre eran comerciantes y personas de confianza nombrados por el Consejo de Indias, adinerados e influyentes. Debido a su comercio con América se estableció primero en Cádiz y, definitivamente, en Sevilla, donde fallecería el 10 de febrero de $1648^{18}$. La documentación de la que disponemos confirma que Amezqueta estuvo en el Nuevo Mundo entre 1636 y 1639 o $1640^{19}$. El 25 de abril de 1636 salió con la flota a cargo del general Carlos de Ibarra rumbo a Cartagena, en la que tomaron puerto el 29 de junio. Tras detenerse allí unos pocos días, zarparon hacia Portobelo (Panamá), al que llegaron el día 10 de julio ${ }^{20}$. Amezqueta "iba con cargazón a Puertobelo para subir desde allí a Lima, como lo hizo"21. Según lo que nos cuenta la Carta, debió permanecer en Lima hasta julio o agosto de 1637. Desconocemos qué tipo de negocios lo llevarían al Potosí, pero es indudable que tendrían que ver con el comercio y, concretamente, con la plata allí extraída.

Los vascos tuvieron una presencia considerable en el sector minero del Potosí y, asimismo, en la navegación al Nuevo Mundo, con porcentajes muy altos de marinos y maestres de nao vizcainos en la Carrera de Indias ${ }^{22}$. De modo que la trayectoria profesional y personal de Amezqueta, con el eje San SebastiánSevilla-América, responde a patrones nada excepcionales en

España, 1630-1631: vicisitudes y naufragios, coord. Flor Trejo Rivera, INAH, México, 2003, pp. 245-298, esp. pp. 281-295, donde se estudian los pleitos que Amezqueta sostuvo a raíz del naufragio de la nao San Antonio, de la que era capitán, en 1631 frente a las costas de Tabasco.

18 En 1627 se declara vecino de la ciudad de Cádiz (AGI, Contratación, 647A, n. 2, r. 10), pero a partir de 1629 (AGI, Contratación, 819, n. 11), si no antes, debió mudarse a Sevilla, donde estableció su residencia principal "en la colación de Santa María la Mayor". Así lo indica su testamento, que fue abierto el 11 de febrero de 1648, un día después de su muerte.

${ }^{19}$ En el Archivo Histórico Provincial de Sevilla, Sección de Protocolos, no hay rastro de Baltasar de Amezqueta en los índices correspondientes a los años 1638-1639 (signatura 18502). Vuelve a aparecer en la documentación relativa al año 1640 (por ejemplo, en 10170, ff. 1031 $1^{\mathrm{r}}-1033^{\mathrm{v}}$ ).

20 AGI, Contratación, 833, n. 13; Suardo, Diario, t. 2, p. 142.

21 AGI, Contratación, 833, n. 13, f. 35v .

22 Lutgardo García Fuentes, "Los vascos en la Carrera de Indias en la Edad Moderna: una minoría dominante”, Temas Americanistas, 16 (2003), 29-49. 
el siglo Xvir. Desde luego, la grandeza de san Ignacio, de su Compañía y de la iglesia de San Pablo ensalzada en la Carta sería motivo de orgullo para los vascos y navarros que, como Amezqueta, comerciaban con América o se habían establecido allí. El poema indica que unos "ochenta vizcaínos" (v. 729) participaron en la procesión, y también los recuerda como miembros destacados de los festejos el Diario de Medrano ("toda la nación vascongada") y la anónima Relación succinta impresa en 1639 ("un lucido escuadrón de la nobleza de Vizcaya") ${ }^{23}$. Baltasar de Amezqueta se sentiría particularmente halagado por estos detalles, puesto que siempre mantuvo estrechos vínculos con los vascos. De hecho, al redactar su testamento, pidió que lo enterraran en la capilla de la nación vascongada de Nuestra Señora de la Piedad, en el convento de San Francisco de Sevilla.

Pese al lugar de relieve que ocupan en el texto, los vascos son tan solo un aspecto de un panorama humano mucho más complejo perfilado en la Carta. La relación poética que Menandro ofrece a su amigo Fabio puede leerse tanto como un informe arquitectónico y religioso, cuanto como un breve extracto de crónica social. La atención principal recae, obviamente, en los miembros de la Compañía de Jesús, representados como un grupo poderoso y triunfante, poniendo especial énfasis en su alianza con los agustinos, que "están hoy con tanta unión / y sus hijos tan hermanos / que hoy el hijo de Agustino / es también hijo de Ignacio" (vv. 949-952) ${ }^{24}$. Esta unión de fuerzas se asienta sobre el espacio simbólico del templo de San Pablo, al cual los agustinos y el resto de la sociedad limeña han sido invitados para admirar la grandeza y la magnificencia de la Compañía, reflejada en su monumental iglesia: "el templo / más perfecto y acabado / [...] / de los que en Lima hasta ahora / habemos visto acabados" (vv. 221-222 y 231-232). No es una casualidad que se insista en las cantidades de dinero invertidas en su edificación, sus materiales de lujo y el espacio descomunal de este edificio, que, a todas luces, pretendía competir con la catedral de Lima.

23 SuARdo, Diario, t. 2, p. 187; Relación succinta, f. $1^{\mathrm{v}}$.

${ }^{24}$ Esta alianza queda de manifiesto también en los festejos que tuvieron lugar en Lima el 28 de agosto de 1636: "Este día del glorioso patriarca san Augustín se celebró su fiesta en la iglesia del convento de esta sagrada religión, y oficiaron la misa mayor y las vísperas primeras el padre provincial de la Compañía de Jesús, Antonio Vázquez, y todos los padres del Colegio de San Pablo" (Suardo, Diario, t. 2, p. 140). 
Las dotes descriptivas del autor de la Carta son notables, y dan debida cuenta de la suntuosidad de la que llama "la mejor fiesta / que en Lima se ha celebrado" (vv. 1389-1390). En sus versos desfilan los jesuitas, los agustinos, el virrey, los miembros de la Real Audiencia y de la Inquisición, los esclavos negros, los indios, el pueblo menudo, configurando un cuadro en movimiento que recorre las calles de Lima y que se deleita con los retablos barrocos, la música y los fuegos artificiales. La iglesia de San Pablo es el gran foco de atracción en torno al cual se reúne toda la ciudad, con sus grandezas y sus pequeñas miserias, que el poeta Menandro identifica sobre todo en las vanidades y comportamientos ostentosos de las clases pudientes. Este templo nuevo, que no "está acabado del todo" (v. 109), es producto de una comunidad que se concibe a sí misma como una entidad rica, compleja y en constante desarrollo, que expresa su poderío a través de lo sólido y monumental, San Pablo, y de lo fluido y escurridizo, los festejos públicos. Como bien supo captar otro contemporáneo, es en el acontecimiento multiforme de la fiesta donde se vislumbra más nítidamente la esencia espectacular de la sofisticación y riqueza de la sociedad limeña:

Siempre tienen en Lima muchas fiestas, grandes procesiones con muchas danzas y mucho estruendo de instrumentos, y con tantas invenciones que en España no hay ciudad donde hagan tantas cosas como en Lima, ni donde cuelguen las calles con más riquezas $^{25}$.

\section{Criterios de EDición}

Probablemente el texto de la Carta sea autógrafo. El autor redactó su romance con una letra muy clara, pero cometiendo unos cuantos errores ${ }^{26}$. En el aparato crítico final se han consignado

25 Descripción del Virreinato del Perú. Crónica inédita de comienzos del siglo XVII, ed. Boleslao Lewin, Universidad Nacional del Litoral, Rosario, 1958, pp. 54-55. El autor de la crónica fue Pedro de León Portocarrero, quien debió componerla en torno a 1620. Acerca de la importancia de lo espectacular en la sociedad y en la literatura del Nuevo Mundo, véase Stephanie Merrim, The spectacular city, Mexico, and colonial Hispanic literary culture, University of Texas Press, Austin, 2010.

${ }^{26}$ Esto sugiere varias posibilidades: o bien se trata de una versión en limpio hecha por el mismo autor o un copista a partir de un borrador original, o bien el texto le fue dictado a un copista. 
todas las enmiendas que he realizado y las correcciones hechas por el autor (o el copista) en el manuscrito original. Salvo en casos de errores de copia muy claros, he preferido no intervenir con conjeturas para enmendar los versos hipermétricos, pues estos parecen deberse a menudo a deslices del autor, de los que es preciso dar cuenta. He modernizado la ortografía del poema siguiendo las convenciones actuales, pero respetando todas aquellas grafías que tienen valor fonético e histórico, como por ejemplo la simplificación de los grupos consonánticos cultos (estremos, espresado, colunas), su mantenimiento (subcedido, sumptuosa), la vacilación de las vocales átonas (confisionarios, penáculo, siguro, munumento), la falta de aspiración de la $g$ intervocálica (agora), la contracción de la preposición de seguida de pronombres o demostrativos (dellas, dellos, desta, deste), y otras grafías que podrían manifestar usos particulares del autor (la metátesis catredal, las vacilaciones petril/ pretily santo/sancto). Este debía ser seseante (relasiones, apresiado, engrandese), aunque sus usos gráficos no son siempre coherentes (autoriza, pobreza, pareçeres). He desarrollado las abreviaturas y regularizado el empleo de $s / z$, $n / m$ y $x / i / y / j$. La puntuación ha sido modernizada, siguiendo sobre todo un criterio sintáctico antes que prosódico y métrico. Esto implica que, en ocasiones, las sinalefas pueden verse separadas por comas. Tampoco he marcado gráficamente las diéresis, sinéresis y otros recursos métricos similares. Mi objetivo principal ha sido el de ofrecer un texto que pudiera leerse y entenderse de la mejor forma posible. Estos son los mismos criterios que he seguido en la transcripción de las fuentes primarias citadas en este artículo. Las notas a pie de página pretenden aclarar sobre todo el significado de palabras hoy en desuso, además de referencias a hechos, lugares o personas del siglo XVII.

Rodrigo Cacho Casal Clare College University of Cambridge 


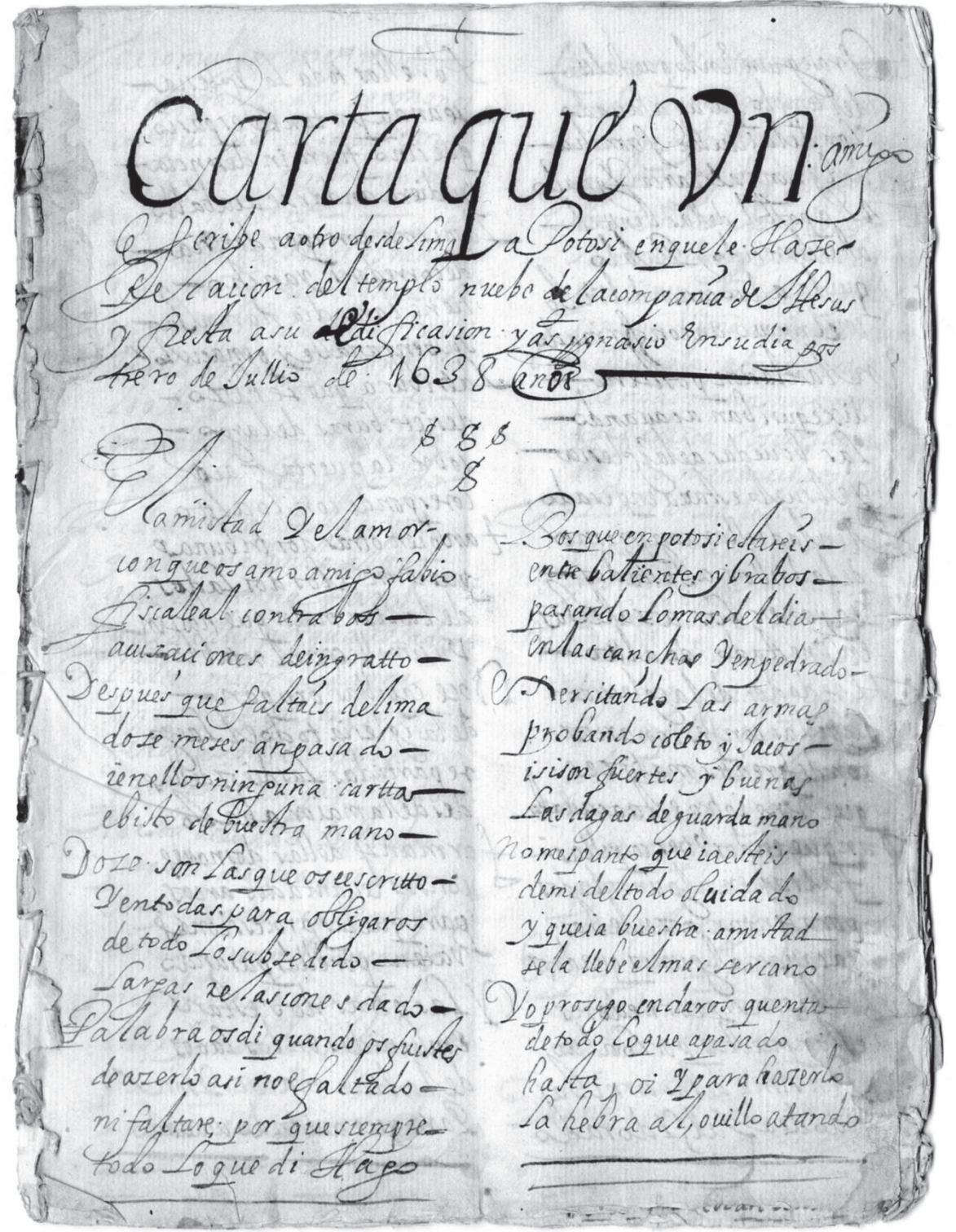

Imagen 2. Hispanic Society of America, ms. B2506, f. $1^{r}$. 
40

RODRIGO CACHO CASAL

NRFH, LXIV

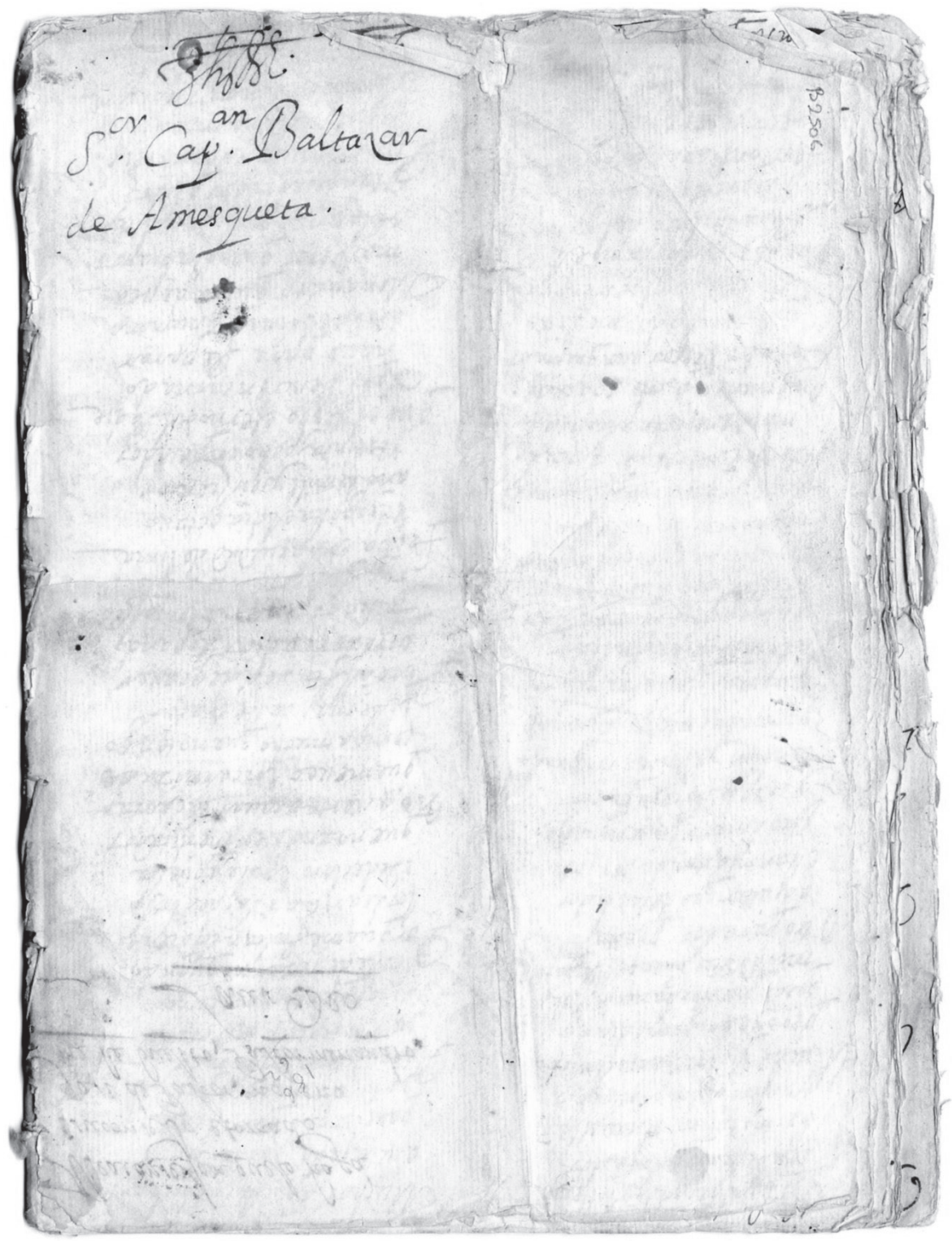

Imagen 3. Hispanic Society of America, ms. B2506, f. 15". 
Abreviaturas

AGI: Archivo General de Indias (Sevilla).

Anua 1638: Carta anua del padre Antonio Vázquez, Lima, 25 de mayo de 1638 (ARSI, Peru 15, ff. 99 ${ }^{\mathrm{r}}-126^{\mathrm{r}}$ ).

Anua 1639: Carta anua del padre Nicolás Durán Mastrilli, Lima, 30 de mayo de 1639 (ARSI, Peru 15, ff. 127 $7^{\mathrm{r}}-155^{\mathrm{v}}$ ).

ARSI: Archivum Romanum Societatis Iesu (Roma).

Autoridades: Diccionario de Autoridades, ed. facsímil, Gredos, Madrid, 1990, 3 ts.

Bromley: Juan Bromley, "La ciudad de Lima en 1630", Revista Histórica, 24 (1959), 268-317.

Correas: Gonzalo CoRreas, Vocabulario de refranes y frases proverbiales, ed. Víctor Infantes, Visor/Libros, Madrid, 1992.

Covarrubias: Sebastián de Covarrubias, Tesoro de la lengua castellana o española, ed. Martín de Riquer, Alta Fulla, Barcelona, 1998.

Mendiburu: Manuel de Mendiburu, Diccionario histórico-biográfico del Perú. Parte primera, que corresponde a la época de la dominación española, Imprenta de J. Francisco Solís, Lima, 1874-1890, 8 ts.

\section{Texto}

Carta que un amigo escribe a otro desde Lima a Potosí, en que le hace relación del templo nuevo de la Compañia de Jesús y fiesta a su edificación y a san Ignacio en su día postrero de julio de 1638 años

El amistad y el amor con que os amo, amigo Fabio, fiscal leal contra vos acusaciones dé, ¡ingrato!

5 Después que faltas de Lima, doce meses han pasado y en ellos ninguna carta he visto de vuestra mano.

3 fiscal: "El ministro diputado para defender el derecho del rey en los pleitos civiles en que tiene algún interés y, en lo criminal, para poner la acusación de los reos que cometen qualesquiera delitos... Por ampliación se llama el que acusa o redarguye a otro de cualquiera operación mal hecha" (Autoridades). 
Doce son las que os he escrito y en todas, para obligaros, de todo lo subcedido largas relaciones dado.

Palabra os di cuando os fuistes de hacerlo así: no he faltado

15 ni faltaré, porque siempre todo lo que digo, hago.

Vos, que en Potosí estaréis, entre valientes y bravos, pasando lo más del día

20 en las canchas y Empedrado, ejercitando las armas, probando coleto y tacos y si son fuertes y buenas las dagas de guardamano.

No m'espanto que ya estéis de mí del todo olvidado y que ya vuestra amistad se la lleve el más cercano.

Yo prosigo en daros cuenta de todo lo que ha pasado hasta hoy; y para hacerlo, la hebra al ovillo atando, proseguiré en lo que falta del templo que han acabado los de la ilustre familia del gran patriarca Ignacio, el apóstol de las gentes, al esclarecido Pablo, que la advocación del viejo en el nuevo han confirmado.

18 entre valientes y bravos: el Potosí tenía fama de ser una ciudad donde las reyertas y los asesinatos eran frecuentes. Esta reputación se remontaba sobre todo a los violentos enfrentamientos entre vascos y españoles procedentes de otras regiones ("vicuñas") durante la década de 1620. Véase Jurgi Kintana Goiriena, "La nación vascongada y sus luchas en el Potosí del siglo xviI. Fuentes de estudio y estado de la cuestión”, AEA, 59 (2002), 287-310.

20 cancha: "corral o patio" (Gramática y vocabolario en la lengua general del Perú llamada quichua, y en la lengua española, Clemente Hidalgo, Sevilla, 1603); Empedrado: zona en la parte superior derecha de la plaza Mayor del Potosí, como puede verse en un mapa de hacia 1590 comentado por Peter Bakewell, "Mining Mountains", en Mapping Latin America: A cartographic reader, eds. Jordana Dym \& Karl Offen, The University of Chicago Press, Chicago-London, 2011, pp. 61-64. En el Empedrado se reunían bravos y personajes de mala vida, y fue teatro de duelos y reyertas violentas en el siglo Xvir. Véase David Dressing, Social tensions in early Seventeenth-Century Potosí, tesis, Tulane University, 2007, p. 68, n. 40.

22 coleto: "casaca o jubón" de piel, que solían vestir los soldados y los hombres de armas: "sirven a los soldados para adorno y defensa" (Autoridades); taco: "la baqueta con que se aprieta el arcabuz después de cargado" (Covarrubias).

24 guardamano: guarnición junto al puño de la espada "para preservar la mano de las heridas" (Autoridades). 
En la relación postrera

dije que iban acabando

las bóvedas de la iglesia

y el suelo estaba empezado

45

a enladrillar con primor

de ladrillos ajustados

y a poner los azulejos

en un estado de alto;

alrededor de la iglesia:

50 capillas, confisionarios, con diferentes matices, que uno y otro está acabado,

aunque en dos u tres capillas

55

faltan en algunos lados

por asentar azulejos

y acabar algunos cuadros.

Balcones y corredores

están puestos por lo alto

y encima de las cornisas

60

todo de azul y dorado.

Por ellos toda la iglesia

se anda por tanto espacio

que, si no fuera indecencia,

65

pudiera andarse a caballo.

La misma correspondencia

de corredores y ancho

tiene la media naranja,

su ventanaje y penáculo.

La tribuna, que se hizo

70 de siete varas de largo

sobre la puerta mayor,

corresponde con lo alto.

43-46 Compárese con Anua 1639: "siendo toda ella de cal y ladrillo, cubierta de bóveda sobre hermosísimos arcos" (f. 130v).

48 'a la altura de un estado'; estado: "cierta medida de la estatura regular que tiene un hombre; y de ordinario la profundidad de los pozos o de otra cosa honda se mide por estados. Entre los albañiles y maestros de obras y canteros las paredes que se hacen de cantería se miden por estados" (Autoridades).

57-64 Compárese con Anua 1638: "A toda la iglesia en torno cerca por arriba una reja de balaustres de azul y oro, con dos balcones en los brazos de crucero y también alrededor de su media naranja, con que da hermosísima vista a todos los que están en el templo. Por estos balaustres se puede andar toda la iglesia con comodidad" (f. 101 r); y Anua 1639: "Está rodeada toda sobre la cornisa de balaustres de oro y azul, de suerte que, a más que esta coronación la hermosea mucho, puede comunicarse toda por ellos con gran comodidad hasta la tribuna" (f. 131 ${ }^{\mathrm{r}}$ ).

67 media naranja: 'cúpula'.

68 penáculo ("pináculo'): "La parte superior y más alta de algún edificio magnífico o templo" (Autoridades).

69 tribuna: "la ventana de alguna iglesia con balcón o celosía, donde con recogimiento y separación asisten los príncipes o personas de distinción a los oficios divinos" (Autoridades).

70 varas: la vara era una medida que oscilaba entre los 768 y 912 milímetros. 
También otras dos tribunas

75

pusieron a los dos lados

del altar mayor, que hacen

un símil con el retablo.

Doce capillas ocupan

de la iglesia todo el largo, repartidas las diez dellas

80 desde la mayor abajo.

Fórmanse dellas dos naves

con sus levantados arcos

para que las procesiones

vayan por ellas pasando.

85 Y las otras dos están

embebidas en los lados

del altar mayor y son

para que, habiendo acabado

de comulgar, se retiren

90 a dar gracias los hermanos

con quietud y devoción,

sin que los estén mirando.

La capilla mayor es

la mejor que se ha labrado

95 en Europa ni en las Indias

y esto testifican cuantos

de allá vienen y que han visto

lo hasta agora edificado

en conventos religiosos,

$100 \quad$ catredales reservando.

Media naranja la cubre

y la corona en lo alto

una lanterna, farol

que da luz por cuatro lados.

105

$\mathrm{Al}$ altar mayor le adorna

un eminente retablo

73 dos tribunas: "Tiene el altar mayor dos capaces aposentos a los lados para dar gracias, con sus tribunas por de dentro que salen también voladas al mesmo altar mayor. Por estos aposentos se ha de salir a decir misa a la iglesia" (Anua 1638, ff. 100 $-101^{\mathrm{r}}$ ); "sobre el altar mayor, a sus dos lados, están dos tribunas capaces que miran al altar y crucero, adonde con secreto pueden oír los oficios y sermones los señores inquisidores y otros personajes que no suelen concurrir en público con el señor virrey y Audiencia" (Anua 1639, f. 131²).

77 doce capillas: la iglesia tenía diez capillas en las naves laterales (cinco en cada una) y dos en el presbiterio. Puede verse un plano en VArgas Ugarte, Los jesuitas, láminas 3a y 3b.

100 'excluyendo a las catedrales'; reservar: "Significa también exceptuar o privilegiar de alguna ley común" (Autoridades).

103 lanterna: "fábrica de madera o otro material en figura de seis o ocho lados con otras tantas ventanas o aberturas para que entre la luz, la cual se pone para este efecto en lo alto de los edificios y, muy comúnmente, sobre las medias naranjas de las iglesias" (Autoridades).

105 altar mayor: dedicado a san Pablo y san Pedro, y "en él tiene gran lugar la santísima Virgen y todos nuestros santos" (Anua 1639, f. 131').

106 eminente retablo: en Anua 1638 se describe el retablo en términos semejantes: "El retablo es sin contienda el mejor que hay por acá, y que puede competir en materia y forma con 
de la mejor escultura

que manos han fabricado.

No está acabado del todo,

110 pero, después de acabado,

se ha preciado su valor

en casi cien mil ducados.

Y no admire lo que digo

a los que no le han mirado,

115 que en cuarenta mil se tasa

lo dorado y estofado.

Cuarenta ventanas tiene

todo el templo en alto y bajo:

las dieciocho las capillas,

120 las veinteidós por lo alto.

Estas, sin las claraboyas,

lanternillas y pináculos

que tienen las diez capillas

con que viene a estar tan claro

125 todo el templo a todas horas,

que no hay rincón ni resguardo

que padezca obscuridad

en poco ni en mucho espacio.

130 puestos ya sus encerados

y es el claro de las diez

de cinco varas de marco.

Una reja de madera

de cedro divide el paso

135 de la capilla mayor

a lo demás de hacia abajo.

Otras también se pusieron

de más pequeño tamaño

para dividir los puestos

140 de mujeres y d'escaños.

El púlpito le pusieron

al lado izquierdo del arco

de la capilla mayor,

tan vistoso y tan labrado

lo aventajado de Europa... No está aún acabado, y lo hecho se aprecia en madera en más de ochenta mil pesos de plata, y deste color se habrá de quedar algunos años, porque habrá menester para solo oro para el dorado más de treinta mil pesos, sin oficiales" (f. 101 ${ }^{\mathrm{r}}$. Véase también Anua 1639: "Está este retablo en madera del mesmo color del cedro, y no acabado, pero es gran cosa y será hermosísimo cuando se dore" (f. 131 $)$.

116 estofado: adorno que resulta de estofar: "En el arte de los doradores es raer con la punta del instrumento, que ellos llaman grafio, el colorido dando sobre lo dorado de la madera, formando diferentes rayas o líneas, para que se descubra el oro que está debajo y haga visos entre los colores con que se pintó" (Autoridades).

130 encerado: "El lienzo aderezado con cera que sirve para resguardar del agua alguna cosa, como las ventanas, los coches, la ropa y otras semejantes" (Autoridades).

131 claro: 'claraboya' o 'tronera'. 
145 de una escultura tan prima de labor a lo mosaico que tiene el primer lugar de los que están acabados.

De linda madera hicieron

150 las tres puertas y clavaron con la clavazón de bronce y mascarones vaciados.

Allanose la plazuela y de nuevo la empedraron

155 y cercaron con petril de vara y media de alto.

Hiciéronle cuatro entradas y gradas hicieron cuatro para subir a la iglesia

$160 \quad$ con descanso y sin trabajo.

La mitad del frontispicio, desde la cornisa abajo del lienzo de la portada, enlucieron y encalaron,

165 y encima lo blanco dieron color de piedra que hallaron tan a propósito que hace natural lo que es prestado.

Sobre la puerta mayor

170 de piedra un escudo ancho tiene esculpido un Jesús y encima está un epitafio con unas letras latinas que dicen en castellano: "Es del nombre de Jesús con advocación de Pablo".

145 prima: 'primorosa, excelente'.

152 mascarones: "Llámanse así regularmente unas caras muy grandes y disformes con que se cubren los rostros ridículamente; y por semejanza se llaman así las que fingen en las fuentes o otras obras de arquitectura" (Autoridades).

155 petril ('pretil'): "El antepecho o vallado de piedra o otra materia que se pone en algunos edificios" (Autoridades). Este "pretil de cal y canto" separaba el cementerio de la plazuela que se encontraba en frente de la iglesia (Anua 1639, f. 131 ${ }^{\mathrm{r}}$ ).

164 enlucir: "Blanquear las paredes dándolas con paños que llaman de yeso, para que queden limpias" (Autoridades).

175-176 Para ser más precisos, la puerta principal del templo tiene una inscripción latina que dice "Invocatum est super nos" (Jeremías 14:9) sobre un escudo con el monograma IHS ("un Jesús"). Así lo indica también Anua 1639: "en medio [de la fachada] una tarja de piedra de 3 varas de alto y ancho en proporción encima de la puerta principal de excelente arquitectura, en medio de quien releva un buen espacio sobre que está escrito el nombre de Jesús y alrededor, como por mote, Invocatus [sic] est super nos" (f. 131 ${ }^{\mathrm{r}}$ ). 
La una de las dos torres que hacen frente a los dos lados

180 de sumptuosa grandeza

$\begin{array}{cl}180 & \text { de todo punto acabaron, } \\ & \text { y campanas y reloj } \\ & \text { que da las horas y cuartos, } \\ \text { que cinco por todas son, } & \text { en ellas se colocaron. } \\ & \text { El repique de ellas es } \\ & \text { tan sonoro y concertado } \\ & \text { que las mejores de Lima } \\ \text { no dan adelante un paso. } & \text { De ciento y veinte quintales } \\ & \text { otra campana forjaron, } \\ & \text { tan grande que el peso dice } \\ & \text { lo que será su tamaño. } \\ & \text { Esta salió tan perfecta } \\ & \text { y de sonido tan claro } \\ \text { que sin duda excede a todas } & \text { las que en Lima se han vaciado. } \\ & \text { La otra torre es lugar } \\ & \text { para ella dedicado } \\ & \text { y así la tienen al pie } \\ & \text { para subirla a lo alto. } \\ & \text { Si por de dentro es vistoso, } \\ \text { también por defuera es tanto } & \text { que casi estoy por decir } \\ & \text { que tiene mejor ornato. } \\ & \text { Cuatro torres la hermosean } \\ & \text { las cuatro esquinas y lados } \\ & \text { y por todo el edificio } \\ & \text { muchas de menor tamaño. } \\ & \text { Cornisas, globos, agujas } \\ & \text { por adorno en los espacios } \\ \text { del lienzo de las paredes, } \\ \text { todo bien proporcionado; }\end{array}$

177-188 Compárese con Anua 1638: "En la una destas [torres], que ya está acabada, con su lanterna y corredores, hay siete campanas que cuando se tocan son de alegría a la ciudad" (f. $101^{\mathrm{r}}$ ).

190 otra campana: se trata de la campana que el obispo de Chile bautizó el 29 de julio de 1638 con el nombre de San Agustín: "el señor obispo de Santiago de Chile, don fray Gaspar de Villarroel, gustó de bendecirnos una gran campana para la segunda torre, que pesa 108 quintales" (Anua 1639, f. 131v). Según Medrano pesaba "179 quintales" (SuARdo, Diario, t. 2, p. 187). Acerca de las campanas de la iglesia, véase VArgas Ugarte, Los jesuitas, p. 40. Sobre Villarroel, véase el v. 1246.

209 aguja: "obelisco o pirámide que viene a rematar en punta, y también el capitel de una torre que es de esta hechura" (Autoridades).

211 lienzo: "la fachada del edificio o pared que corre de un ángulo a otro en cualquier aposento" (Autoridades). 
con corredores la torre por delante y por los lados, ventanas del frontispicio y la cornisa de abajo.

De piedra, ladrillo y cal está todo edificado, con que para los temblores 220 viene a ser de gran reparo.

En conclusión, es el templo más perfecto y acabado por de dentro, por defuera, por el suelo, por lo alto, 225 en lo curioso, en lo fuerte, en lo ancho y en lo largo, en lo alegre, en lo vistoso, en lo apacible, en lo claro, en lo alto y sumptuoso

230 y en lo más bien adornado de los que en Lima hasta ahora habemos visto acabados.

Es para el verano fresco, para el invierno abrigado, porque aquestos dos efectos previenen los encerados.

Esta es opinión de todos y alguno hay que le ha llamado el Salomón de las Indias, si no en riqueza, en bizarro.

Solo en aquesta opinión no vienen los mercenarios, porque dicen que es el suyo a todos aventajado.

213-216 Había corredores tanto en la torre como en las ventanas de la fachada y en la cornisa inferior del edificio.

217 De piedra, ladrillo y cal: "este edificio se ha acabado, todo de cal y ladrillo" (Anua 1638, f. $100^{v}$ ); "fortísimos cimientos de cal y canto, siendo toda ella de cal y ladrillo" (Anua 1639, f. 130v).

219 los temblores: "ha quedado, gracias a nuestro Señor, fuerte para los temblores, hermoso y capaz para su frecuencia" (Anua 1638, f. 101 ${ }^{\mathrm{r}}$ ); "Es fortísima, como lo persuade en esta ciudad el miedo de sus grandes temblores de tierra, y en esta parte se habla de experiencia, porque los ha resistido mientras se hacía, valentísimos, sin mostrar flaqueza" (Anua 1639, ff. 130 $0^{\mathrm{v}}-131^{\mathrm{r}}$ ). Alude sobre todo al terremoto del 27 de noviembre de 1630, que, según Suardo, fue uno "de los más grandes que ha habido desde cincuenta años a esta parte (Diario, t. 1, p. 121). Suardo da cuenta de otras sacudidas menores, como la del 3 de julio de 1635 (Diario, t. 2, p. 86).

233 para el verano fresco: "muy hermosa a la vista y muy fresca para sus concursos (cosa necesaria en este temple)" (Anиа 1639, f. 131 ${ }^{\mathrm{r}}$ ).

239 Salomón de las Indias: alude al legendario y fastuoso templo del rey Salomón, descrito en el Antiguo Testamento (sobre todo en 3 Reyes 6 y 2 Paralipómenos 3-4).

242 mercenarios: 'mercedarios'. En el siglo XVII se empleaban ambos vocablos para referirse a los frailes de la Merced.

243 el suyo: debe aludir a la basílica de Nuestra Señora de la Merced de Lima, fundada en 1535. Cobo la describe en su Historia: "La iglesia edificaron al principio de muy buena obra para 


\begin{tabular}{|c|c|}
\hline \multirow{2}{*}{245} & Y que con ese siguro \\
\hline & $\begin{array}{l}\text { lo digan yo no me espanto, } \\
\text { gue vo lo mismo dijera }\end{array}$ \\
\hline \multirow{3}{*}{250} & $\begin{array}{l}\text { si me hallara mercenario: } \\
\text { yo alabara mis agujas, }\end{array}$ \\
\hline & $\begin{array}{l}\text { aunque les faltaran cabo, } \\
\text { pero más cierta alabanza }\end{array}$ \\
\hline & es la del común aplauso. \\
\hline \multirow[b]{2}{*}{255} & $\begin{array}{l}\text { Ha tenido mucha costa, } \\
\text { aunque hecho en pocos años; }\end{array}$ \\
\hline & mas, de uno y medio a esta parte, \\
\hline \multirow[b]{3}{*}{260} & Pero tomaron un medio \\
\hline & $\begin{array}{l}\text { los padres, y fue acertado, } \\
\text { que eligieron uno dellos }\end{array}$ \\
\hline & $\begin{array}{l}\text { para que se hiciese cargo } \\
\text { de toda la obra dél. }\end{array}$ \\
\hline & $\begin{array}{l}\text { Y para ello fue nombrado } \\
\text { uno de los padres graves, }\end{array}$ \\
\hline \multirow[t]{2}{*}{265} & $\begin{array}{l}\text { asperto y de mucho agrado. } \\
\text { Este en menos de año y medio }\end{array}$ \\
\hline & ha hecho y facilitado \\
\hline \multirow[b]{3}{*}{270} & cosas que son increíbles \\
\hline & $\begin{array}{l}\text { y que parecen milagro: } \\
\text { bóvedas, torres, balcones, }\end{array}$ \\
\hline & $\begin{array}{l}\text { azulejos, ladrillado, } \\
\text { portadas, rejas, pretil, }\end{array}$ \\
\hline & $\begin{array}{l}\text { las campanas y retablos, } \\
\text { tribunas, gradas, faroles, }\end{array}$ \\
\hline & $\begin{array}{l}\text { santos de bulto estremados, } \\
\text { púlpito, altares, ventanas }\end{array}$ \\
\hline & y para ellas encerados. \\
\hline
\end{tabular}

aquel tiempo, de una grande nave cubierta de tablas, con capillas a los lados. De esta forma sirvió muchos años hasta el virreinado del marqués de Montesclaros, que la comenzaron a renovar o, por mejor decir, a edificar de nuevo, mucho mayor y de más suntuosa fábrica que antes tenía. Viene a quedar de tres naves, va toda ella de ladrillo y cal con muy fuertes y anchos estribos, cubierta de bóvedas de crucerías muy fuertes y galanas" (p. 257).

245 siguro: 'seguridad, certeza'.

248 si me hallara: 'si fuera'.

249-250 Alude al refrán "Cada buhonero alaba sus agujas" (Correas), glosado así por Autoridades: "da a entender que cada uno alaba sus obras y sus trabajos".

259 uno dellos: el hermano Martín de Aizpitarte (o Azpitarte), "eminente en el oficio de cantero", se encargó de dirigir los trabajos de construcción de San Pablo hasta 1637, cuando murió a los 73 años de edad (Carta anua del padre Antonio Vázquez, Lima, 25 de mayo de 1637, ARSI, Peru 15, ff. $77^{\mathrm{r}}-96^{\mathrm{v}}$; f. $80^{\mathrm{v}}$ ). Sin embargo, el poema parece referirse a un jesuita que todavía vivía en 1638. Podría tratarse del hermano Andrés Alonso o del hermano Nicolás de Villanueva, que se emplearon como alarifes (VARGAS UGARTE, Los jesuitas, p. 25).

264 asperto: 'experto'.

274 bulto: 'imagen de madera'. 
Derribó del templo viejo un temerario pedazo para cuadrar la plazuela, 280 que costó mucho trabajo.

En conclusión, ha hecho cosas que parece son milagros, y, si hubieran d'escrebirse, ocuparan tiempo largo.

$285 \quad$ Y ha hecho más en año y medio que otros hicieran en cuatro, porque ninguno como él lo hubiera facilitado.

Porque con tanto oficial, 290 unos negros y otros blancos, no sé cómo se entendía, ni cómo daba recaudo; dónde buscaba dinero para pagar tanto gasto

295 de oficiales y peones, pagándoles su trabajo.

Estando, pues, como he dicho el templo en aqueste estado, se asignó que fuese el día

300 del gran patriarca Ignacio, el de su renovación, a cuya fiesta agregaron la del Corpus, que no habían este año solemnizado;

305 con que juntaron tres fiestas: Corpus Criste, san Ignacio y renovación del templo que en una se celebraron.

Y antes que llegase el día

310 se tuvo por acertado el bendecirse y se hizo con moderado aparato.

Salieron todos los padres sacerdotes, los hermanos

289 oficial: 'obrero'.

293 dinero: "Empezaron [los jesuitas] el año veinte y cuatro un suntuoso templo, con más ánimo y espíritu que caudal, en que han gastado los principales de muchas de sus rentas, con liberalidad estraña, sin reparar en los aprietos que quedan de tan grande como lucido empeño" (Relación succinta, fol.1 ${ }^{\mathrm{r}}$ ).

301 renovación: el día de san Ignacio de Loyola es el 31 de julio.

303 Corpus: el día 3 de junio de 1638. Medrano afirma que el día 30 de junio el virrey fue "al colegio de la Compañía de Jesús a la fiesta que en él se celebra al apóstol san Pablo y juntamente la del santísimo sacramento de Corpus Christi” (Suardo, Diario, t. 2, p. 185). Sin embargo, estos festejos no pudieron tener lugar en la nueva iglesia de San Pablo, "por no estar enjuto el pavimento" (Relación succinta, fol.1 ${ }^{\mathrm{r}}$ ). 


$\begin{array}{cl}315 & \text { todos con sobrepellices } \\ & \text { en procesión y cantando. } \\ & \text { Bendíjole el provincial } \\ & \text { en el modo acostumbrado } \\ & \text { y forma que lo dispone } \\ & \text { el ceremonial romano. } \\ \text { Dijo la primera misa, } \\ \text { que con música oficiaron } \\ \text { los músicos de la iglesia } \\ \text { catredal y del Cercado. } \\ \text { Acudió muy gran concurso, } \\ \text { con no haberse publicado } \\ \text { el bendecirle este día } \\ \text { y estar todos descuidados. } \\ \text { Mas a todos recibió } \\ \text { el templo sin embarazo, } \\ \text { porque en su capacidad } \\ \text { cabe mucho con descanso. } \\ \text { Comenzaron adornar } \\ \text { los altares con retablos: } \\ \text { el de san Javier fue nuevo, } \\ \text { lucidamente dorado. } \\ \text { En él de pincel están } \\ \text { algunos de sus milagros } \\ \text { tan bien pintados que muestran } \\ \text { ser de muy valiente mano. } \\ \text { En otros dos se pusieron } \\ \text { custodias y relicarios }\end{array}$

315 sobrepelliz: "Vestidura de lienzo corta y ajustada al cuerpo, abierta por los costados para sacar los brazos, con unas mangas perdidas muy largas que se rodean al brazo" (Autoridades). Compárese con la descripción de la procesión del 30 de julio que ofrece la Relación succinta: "En que iban docientos y cincuenta hijos de Ignacio con sobrepellices" (fol.1 ${ }^{\mathrm{v}}$ ); y Anua 1639. "Comenzaron a pasar las cofradías con sus andas y mucha cera, las cruces de las parroquias y casi 250 de los nuestros con sobrepellices" (f. $\left.131^{v}\right)$.

317 el provincial: el padre Antonio Vázquez (1578-1670) fue provincial de los jesuitas del Perú de 1634 hasta finales de 1638. Véase EnriQue Torres Saldamando, Los antiguos jesuitas del Perú. Biografías y apuntes para su historia, Imprenta Liberal, Lima, 1882, pp. 199-205.

324 Cercado: la iglesia jesuítica de Santiago del Cercado, fundada hacia 1570 y reedificada en 1601. Véase VARGas Ugarte, Los jesuitas, pp. 76-77.

326 con no haberse: 'pese a no haberse'.

335 san Javier: el altar dedicado a san Francisco Javier. Anua 1638 lo describe así: "Por la parte de dentro tiene el sombrero una paloma en representación del Spíritu Sancto y encima un bulto de nuestro santo padre san Francisco Javier en la forma en que predicaba en sus misiones, de sobrepelliz y estola" (f. 101 ${ }^{\mathrm{r}}$ ). No puede ser la imagen del santo que se encuentra hoy en la iglesia y que es obra tardía -hacia 1645- del taller de Juan Martínez Montañés (VARGas Ugarte, Los jesuitas, p. 38; Alcalá, Fundaciones jesuíticas, pp. 92-97).

340 valiente mano: podría tratarse de los hermanos Bernardo Bitti y Diego de la Puente (VARGas Ugarte, Los jesuitas, p. 25).

342 relicarios: según un memorial de 1661 sobre las reliquias de San Pablo, la iglesia y el colegio tenían "un grande y rico tesoro de reliquias, más precioso que todos los tesoros de la tierra”. Muchas de estas reliquias habían sido traídas de Roma por varios padres de la Compañía (VARGAS UGARTE, Los jesuitas, pp. 30-32). 
que aunque en número son muchos,

$345 \quad$ Muchísimo se juntó

de láminas y de cuadros, colgaduras y preseas para vestir a los santos

y adorno de los altares;

350 todos y todas rogando con lo mejor que tenían, con particular agrado.

$\mathrm{Al}$ retablo del altar mayor se suplió en lo alto

355 lo que falta de madera con doseles y con cuadros.

Catorce altares son todos $\mathrm{y}$ todos tienen retablos de escultura y de pincel

360 ricamente aderezados.

A la entrada de la iglesia, de mármol y de alabastro, pilas para agua bendita en dos basas se asentaron.

$365 \quad$ Yalgunas damas, que llegan sin devoción ni recato a tomarla, prevenidas, llevan el guante calzado, que no quieren competencias

370 con mármoles ni alabastros, aunque poetas las digan que son más blancas sus manos.

Muchas y muchos pidieron puestos para todo el año:

375 las mujeres para alfombras y los hombres para escaños.

Y aunque es el templo muy grande, son tantos los prebendados y las prebendadas tantas que entiendo que antes de Ramos

357 Catorce altares: "Por estos aposentos se ha de salir a decir misa a la iglesia y a los catorce altares que, fuera de los dos relicarios, tiene, cuyos retablos se van disponiendo con la prisa posible" (Anua 1638, f. 101 ${ }^{\mathrm{r}}$ ).

372 blancas sus manos: se burla de los símiles y metáforas hiperbólicas típicos de la lírica petrarquista, donde la tez blanca de la amada se suele comparar con el mármol.

375 alfombras: sobre las que las damas colocaban sus estrados (véase el v. 1194).

378 prebendado: persona que disfruta de una prebenda: "beneficio eclesiástico, como dignidad, canonicato, ración etc." (Autoridades). 
han de andar ellas y ellos, como dicen, a cinchazo: las mujeres a chapines y los hombres a escañazos.

Aquí será bien decir el nuevo asiento tomado para con mayor grandeza hacer fiesta a san Ignacio.

Don Bartolomé Benavides...

390 Bien sé que este verso es largo, que antes que otro lo censure he querido censurarlo.

Digo que este caballero, que es de la iglesia arcediano

395 y de la Santa Cruzada dignísimo comisario, con su liberalidad y con su celo cristiano y por l'amistad que tiene $400 \quad$ a la familia de Ignacio a costa de sus espensas fiesta le ha perpetuado con renta muy suficiente todos los años al santo, 405 para que la catredal, con quien ha capitulado, en solemne procesión le vengan acompañando canónigos, dignidades, 410 racioneros, prebendados, capellanes, clerecía con solemnidad cantando

382 cinchazo: 'a golpes de cincha'; cincha: "Lista ancha de cáñamo, lana o esparto con que se aprieta y asegura la silla o albarda a la cabalgadura" (Autoridades).

383 chapin: "Calzado proprio de mujeres sobrepuesto al zapato para levantar el cuerpo del suelo; y por esto el asiento es de corcho, de cuatro dedos o más de alto, en que se asegura al pie con unas corregüelas o cordones" (Autoridades).

389 Bartolomé Benavides: nacido en Madrid en 1593, se doctoró en cánones por la Universidad de Sigüenza. Pasó al Perú y ocupó varios cargos eclesiásticos, como canónigo, maestrescuela y arcediano de la catedral de Lima y comisario general del tribunal de la Santa Cruzada, además de catedrático en propiedad de nona de teología en la Universidad de San Marcos. Pasó a ser obispo de Antequera (Oaxaca) en 1639. Falleció en 1652 (Bromley, pp. 295-296, n. 60). El provincial de los jesuitas del Perú, Antonio Vázquez, escribió una carta en 1635 en apoyo de la petición de Benavides para el ascenso a prelado, donde dice que es "uno de los más calificados en sangre, benemérito en méritos, lucido en letras, aplaudido en púlpito, ejemplar en virtud y raro en talentos que hay en este reino" (AGI, Lima, 331).

390 este verso es largo: referencia jocosa del poeta al hecho de que el verso anterior es hipermétrico (9 sílabas). Vuelve a aludir a ello en el v. 1292.

401-416 Compárese con Relación succinta: "Bartolomé de Benavides, arcediano desta iglesia, que el año pasado en la iglesia antigua dio principio con otro sermón a la nueva fiesta que ha dotado" (f. $2^{v}$ ). Se trataba, pues, del segundo año que Benavides sufragaba esta fiesta. Lo recuer- 
y con la misma le digan misa y vísperas este año

415 y el sigundo que se hace esta fiesta a san Ignacio.

Y así, con esta ocasión, mucho della tomó a cargo y se hizo como veréis

420 en lo que adelante hablo.

Pero antes de proseguir ni dar adelante un paso quiero, Fabio, preveniros que, si ya habéis reparado

425 y adelante reparáis

en que nombro mucho al santo y que digo muchas veces "el santo", "el santo" y "el santo", que me sirva de disculpa

430 saber que en los coros altos al poderoso uno y trino serafines abrazados continuo están repitiendo "santo, santo, santo, santo"

435 y con este himno y verso su santo nombre ensalzando.

Ya, Fabio, en lo que está escrito, con estilo romo y mazo, lo que es el templo os he dicho

440 y su adorno y aparato,

la prevención de la fiesta, su fundación y el cuidado del que para más solemne la tiene tomada a cargo.

445 Solo falta referirla: no sé cómo ha de ser, Fabio, porque ya los asonantes por los cabellos los traigo.

Porque ya sabéis que soy

450 ignorante laureado, sin natural, sin estudio y de adelantados años.

da también Аnиa 1639: "como se avisó a vuestra paternidad el año pasado, en fiesta de nuestro padre la tiene dotada" (f. 132v).

435 este himno: se refiere a los gozos a la Trinidad que, en una de sus versiones más conocidas, dicen: "Dios uno y trino a quien tanto / arcángeles, querubines, / ángeles y serafines / dicen santo, santo, santo".

438 romo: 'poco agudo'; mazo: 'basto, grosero'. 
Sin duda os admiraréis,

455 esta relación u carta

Fabio, cuando haya llegado

de mi mano a vuestras manos

y juzgo que así diréis:

“¿De cuándo acá, cómo u cuándo

se ha tornado copleador

$460 \quad$ mi buen amigo Menandro?”.

Respondo que aquesta vez

me he metido por donado

en la religión poeta,

que lo es de mentecatos,

465 y también que el amistad

vuestra y devoción de Ignacio

a tan temerario exceso

bastante ocasión me han dado,

mas con propósito firme

470 que no haré jamás pecado

de este género, que es

pecado de hombre menguado.

Y no habéis sido vos solo de los que se han admirado

475 que al cabo de mi vejez

de este mal haya enfermado;

y dicen con disimulo

que disimulado ha estado

este viejo con sus canas

480 y con su rosario largo,

muy torcido de pescuezo,

pensativo, carilacio

y con una elevación

como bulto de retablo.

485

490

$\mathrm{Y}$ aun uno que me conoce

de casi catorce años,

y que accidente como este

en mí jamás ha notado,

dijo con grande cachaza

sonreiéndose al soslayo:

"Perdido va don Beltrán,

sin armas y sin caballo.

464 mentecato: 'loco'. Alude al lugar común según el cual los poetas están poseídos por un furor que los vuelve locos.

482 carilacio: 'cara avejentada'; lacio: "Flojo, marchito o ajado" (Autoridades).

484 bulto: véase el v. 274.

489 cachaza: 'descaro, falta de respeto' (americanismo).

491 don Beltrán: alude de forma jocosa al famoso romance que comienza "Con la grande polvareda / perdimos a don Beltrán”. Este poema narra la muerte de don Beltrán, héroe francés legendario que, según la tradición, participó en la batalla de Roncesvalles. 
Bien le pueden prevenir en San Andrés algún cuarto,

495 que esta bien se ve que es enfermedad de lo alto".

Confieso tienen razón.

¿Qué he de hacer, amigo Fabio, cuando castigan callar?

$500 \quad$ Mas yo cerraré los labios y no los abriré más, si no me lo manda Ignacio; que, si me lo manda, abriré una bocaza de un palmo.

$505 \quad$ Unas coplillas compuse de ciego cuando muchacho y sin duda que de entonces resulta este mal resabio.

Con todas las prevenciones

510 que os he hecho, amigo Fabio... ¿De qué? De decir sin miedo asonantes duplicados, comienzo la relación de la fiesta, e invocando 515 primero el favor del cielo y también de cinco santos, que son Ignacio, Javier, Gonzaga y Estanislao y Borja, que desta fiesta 520 son los más interesados.

Digo, pues, que dos días antes de este invictísimo santo, deste patriarca insigne de hijos santos y sabios, se consagró la campana del grande peso y tamaño que ya queda referido y pusieron en lo alto

494 San Andrés: hospital real de Lima, fundado a mediados del siglo xvi. Entre otras cosas, se señalaba como manicomio del Perú: "más adentro está un patio capaz, y, en torno de él, la vivienda de los locos, porque en este hospital se recogen cuantos se hallan en el reino" (Сово, Historia, pp. 304-305).

496 de lo alto: 'de la cabeza', porque Menandro se ha vuelto loco y escribe poesía.

499 castigan: 'aconsejan' (arcaísmo). Autoridades recoge la siguiente acepción de castigo: "Significa también advertencia, aviso, amonestación y enseñanza”.

506 de ciego: las coplas de ciego son "las que son bajas y malas, como lo son ordinariamente las que venden y cantan los ciegos por las calles" (Autoridades).

516 cinco santos: se trata de los santos jesuitas Ignacio de Loyola (1491-1556), Francisco Javier (1506-1552), Luis Gonzaga (1568-1591), Estanislao de Kostka (1550-1568) y Francisco de Borja (1510-1572).

525 la campana: véase el v. 190. 
de la iglesia aquestas letras

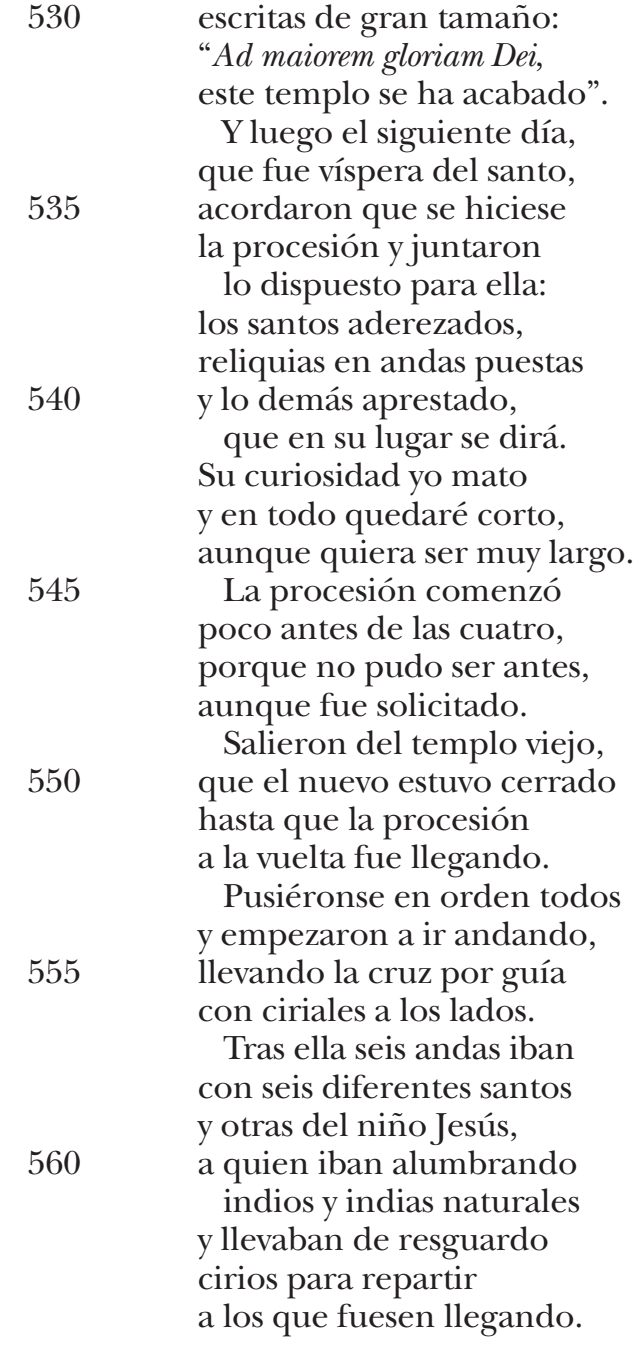


Tras estas siete iban tres de los tres mártires santos naturales del Japón, de varias rosas y ramos de diferentes colores adornadas y adornados y puestos por el ropaje perlas y broches sembrados,

a quien también alumbraban

575 indios y indias con cuidado

$\begin{array}{cl}575 & \text { y sus personas llevaban } \\ \text { todos bien ataviados. } & \text { Estanislao y Gonzaga, } \\ & \text { Borja, Javier, que de Ignacio } \\ & \text { son cuatro hijos y todos } \\ & \text { tan aventajados santos, } \\ & \text { iban siguiendo uno a otro } \\ & \text { como se han ido nombrando, } \\ \text { haciéndose competencia } & \text { en lo más bien adornado. } \\ & \text { Todos con mantos de lama } \\ & \text { negra y blanca, floreados } \\ & \text { de florecitas pequeñas, } \\ & \text { todas de matices varios, } \\ & \text { y de medio cuerpo arriba, } \\ & \text { en cuello, pechos y brazos, } \\ \text { grande inmensidad de perlas } \\ \text { de toda suerte y tamaño } \\ \text { y otra multitud de joyas } \\ \text { de mucho valor que callo, } \\ \text { porque las he de nombrar } \\ \text { en el vestido de Ignacio. } \\ \text { Gonzaga me pareció } \\ \text { que iba más aventajado } \\ \text { que los tres, aunque se quejen } \\ \text { las que los aderezaron. } \\ \text { Las andas en que iban puestos } \\ \text { eran enrejados claustros } \\ \text { de rosas y ramos verdes, } \\ \text { hechos de curiosas manos. }\end{array}$

566 los tres mártires: se trata de los tres santos mártires japoneses de la Compañía de Jesús, Pablo Miki, Juan Soan de Gotó y Diego Kisai. Junto con otros veintitrés mártires cristianos se suelen conocer como "Los veintiséis mártires de Japón”, crucificados en Nagasaki en 1597. Deben ser las mismas imágenes que se habían sacado en procesión en Lima el año 1629 (SUARdo, Diario, t. 1, pp. 12-13).

557-576 Compárese con Anua 1639: "comenzaron a salir el niño Jesús de la cofradía de los indios, nuestros mártires del Japón, nuestros santos canonizados y beatificados" (f. $131^{\mathrm{v}}$ ). dades).

585 lama: "cierta tela de oro o plata, que hoy más comúnmente se llama restaño" (Autori- 
605 Cuarenta y ocho estudiantes

alumbraban estos santos,

que oyen en los estudios

grande, menor y mediano.

Iba en el puesto siguiente,

610 hecho andas un tablado, la niña y madre de Dios, concebida sin pecado,

con Joaquín y Ana, sus padres,

que le van a dar la mano

615 y ella, alargando las suyas,

las recibe con agrado.

Era su ornato de suerte tan lucido y tan galano

que puedo decir que fue

620 quien la afición me ha llevado

en lo curioso y ligero

y en lo bien acomodado,

porque cargazón de joyas

no hacen lucido al santo.

625 Las diademas de los tres, de santa Ana su tocado y de Joaquín el bordón, borceguíes y zapatos

iba todo muy curioso,

630 a lo de nación hebraico, con muy grande propiedad y correspondientes lazos.

Joaquín llevaba en el pecho en joyas diamantes tantos

635 que, como si estrellas fueran, eran brillantes sus rayos,

cadena al cuello de perlas, que cierto, si no me engaño, a mi parecer valía

640 más de cuatro mil ducados.

El tabladillo donde iban era un jardín muy formado, de gran variedad de flores y de verdura de ramos.

609-616 El retablo es descrito también en Anua 1639: "san Joaquín, las santísimas Virgen y santa Ana, bultos que se aventajan a cuantos del género hay en todas las Indias y compiten con todo lo bueno de Europa" (f. 131 ${ }^{\mathrm{r}}$ ). Este grupo escultórico fue enviado en 1628 desde Valladolid por Gregorio Fernández (Alcalá, Fundaciones jesuíticas, p. 92). Compárese con Anua 1639. "la santísima Virgen y sus padres santísimos todos tres en unas parigüelas grandes, con tanto adorno de perlas, joyas y diamantes, que admiraban y entretenían" (f. 131v). 
645 Seis niños, ángeles hechos, con cabellitos dorados, que de velillo de plata y otros colores formado era el vestido de todos,

650 iban puestos a los lados de las andas y llevaban sus candelas en las manos.

Estas tres hechuras son las mejores que han pasado

655 d'España. Solo una falta en todas tres se ha notado y es que no han querido hablar, que solo aquesto ha faltado para tenerlas por vivas, 660 siendo imágines de palo.

De su adorno s'encargó doña Isabel de Menacho y así por eso salió tan perfecto y acabado.

665 Todas tres en un altar en forma de tabernáculo en su lugar cada una de nuevo se han colocado.

Este es el puesto donde iba

670 el invicto san Ignacio tan lucido, tan vistoso, tan ricamente adornado que no sé cómo decir algo dello, porque tanto

675 como era será imposible escribirlo ni espresarlo.

De raso negro llevaba sotana y manteo largo (digo a proporción del cuerpo 680 y de ajustado tamaño),

647 velillo: "una tela muy sutil, delgada y rala que suele tejerse con algunas flores de hilo de plata" (Autoridades).

662 doña Isabel de Menacho: Isabel Pérez de Menacho, nacida en el seno de una importante familia limeña, casó primero con Antonio de Paz (1614) y, tras enviudar, con el almirante Antonio de Morga (1621), que fue nombrado alcalde de Lima en 1623 (Bromley, p. 311, n. 195; Julio Retamal Favereau, Carlos Celis Atria y Juan Guillermo Muñoz Correa, Familias fundadoras de Chile, 1540-1600, Zig-Zag, Santiago de Chile, 1992, p. 433, n. 3). Fue hermana del ilustre padre jesuita Juan Pérez de Menacho, catedrático de teología y autor de numerosas obras eruditas (TorRes SALDAMANdo, Los antiguos jesuitas, pp. 318-322).

672 ricamente adornado: la Relación succinta describe así los adornos del manteo del santo: "hecho un sol, tan ricamente bordado" (f. 1 ${ }^{v}$ ). Anua 1639 ofrece más detalles: "nuestro santo padre con sotana y manteo de seda rasa cuajado de estrellas de oro, piedras y perlas, que se apreciaban en gran suma” (f. 132r). 
bordado de perlas todo y hechos mil curiosos lazos en correspondencia todos, sin estar nada encontrado,

685 y en todos los blancos dellos muchos diamantes sembrados que lucían como estrellas en cielo sereno y claro.

Por las espaldas y hombros

690 iban muchos asentados en joyas grandes, que todas eran cuasi como manos.

Cada diamante era un sol sigún arrojaba rayos,

695 mas, lo que a mí me parece, se los daba el sol Ignacio.

La diadema y el Jesús, que iban a derecha mano, eran diamantes y perlas

700 de precio subido y alto.

Otro llevaba en el pecho y tres en la espalda y lados, con la misma guarnición guarnecidos y bordados.

705 Por la orla y los estremos iban a trechos sembrados muy vistosos camafeos y otras joyas de esmaltado. Una cadena de perlas

710 al cuello de tal tamaño llevaba que la apreciaban en más de tres mil ducados.

Encargose de su adorno

715 Andrés de Zavala digo, que a este glorioso santo y a san Javier su mujer y la que es de Alonso Bravo,

692 manos: aquí con el sentido de 'manojos' o 'manípulos'.

715 Andrés de Zavala: Andrés de Zavala y Urquizu, nacido en Eibar en 1572, era contador mayor del Tribunal de la Santa Cruzada (Bromley, p. 297, n. 75).

717 su mujer: Zavala casó en 1625 con Micaela de la Maza y Usátegui, hija de Gonzalo de la Maza, que, entre otros cargos ejercidos en España y Perú, fue mayordomo del monasterio del Escorial, contador mayor del Consejo Real de Hacienda y contador mayor del Tribunal de la Santa Cruzada. Zavala heredó el puesto de su suegro.

718 la que es de Alonso Bravo: Alonso Bravo, natural de Carmona, fue capitán de navío, mercader y oficial del Santo Oficio (Suardo, Diario, t. 2, p. 70; AGI, Lima, 244, n. 1). Casó con la hermana de Micaela de la Maza, Andrea de la Maza y Usátegui, con la que tuvo tres hijos: María, Alonso y Juan Bravo y de la Maza. Murió en Lima el 29 de abril de 1644 (Mendiburu, t. 2, 
que son hermanas, pusieron tan lucidos y bizarros que se pudo decir dellas el proverbio castellano o refrancillo que dice: "tales manos adornaron a san Ignacio y Javier para que no hayan estado los mejores que se han visto después que se adornan santos".

Más de ochenta vizcaínos

730 con sus cirios en las manos, que el contador convidó, iban alumbrando al santo.

La mayor riqueza fue la de todos cinco santos 735 que en Lima se ha visto junta. En un millón se apreciaron todas las perlas y joyas, y solo de san Ignacio se hizo tasación: valía

740 cuatrocientos mil ducados.

Y un hombre, viendo que iban de tantas joyas cargados y de tan suma riqueza, dijo, estándolos mirando: se fueran aquestos santos así como están, sin duda muchos quedaran llorando".

p. 80; Esteban Mira Caballos y Fernando de la Villa Nogales, Carmona en la Edad Moderna. Religiosidad y arte, población y emigración a América, Muñoz Moya, Sevilla, 1999, p. 365).

724 Tales manos adornaron: alude al refrán recogido por Correas "Tales manos lo hilaron", que glosa así: "Dícese alabando algo con donaire y al autor".

724-728 'Estos santos han sido adornados por tales manos que no cabe duda de que son los mejores que se han visto desde que se adornan santos'.

729 vizcaínos: compárese con el testimonio de Medrano: "en la dicha procesión iban alumbrando toda la nación vascongada" (SuARdo, Diario, t. 2, p. 187); y la Relación succinta: "un lucido escuadrón de la nobleza de Vizcaya con hachas en las manos" (f. $1^{\mathrm{v}}$ ).

731 el contador: Andrés de Zavala; véase el v. 715.

740 cuatrocientos mil ducados: "se apreció en trecientos mil pesos el oro, perlar y piedras que llevaba el manteo", según la Relación succinta (f. $1^{\mathrm{v}}$ ). 
Después de Joaquín y Ana

y la niña y san Ignacio,

llevaban en cinco andas veinteicinco relicarios.

Cada una llevaba cinco con pie alto levantados:

755 uno en medio y los demás puestos en los cuatro lados.

Iban todas tan compuestas

de florestas y de ramos y deversidad de flores

$760 \quad$ que estas y las de los santos

formaban mil primaveras de mil abriles y mayos, güertos, jardines, vergeles y praderías de campos.

765 En los ramos verdes iban pajarillos matizados, tan al vivo contrahechos que, si no es sonoro canto, no les faltaba otra cosa.

770 Mas allí hubieran llegado a cantar los naturales, saltando de ramo en ramo y a dar besos a las flores, si no lo hubiera estorbado

775 el ruido de la gente impidiéndoles el paso.

Noventa y más colegiales del colegio seminario de San Martín el Real

780 las iban acompañando en concertadas hileras y con velas en las manos, que también los colegiales son de la casa de Ignacio.

El lignum crucis llevaban debajo de un blanco palio, alumbrando con sus hachas veinte y cuatro hijos del santo.

749-764 Compárese con Anua 1639: "Seguíanse algunas de nuestras reliquias con singulares adornos de flores hechizas" (f. 132 ${ }^{\mathrm{r}}$ ).

779 San Martín el Real: colegio fundado por los jesuitas en Lima el 11 de agosto de 1582.

785 lignum crucis: "el santo lignum crucis debajo de un lucidísimo palio que llevaban los regidores desta ciudad" (Relación succinta, f. $1^{v}$ ); "y el santo lignum crucis, que llevaba otro de los nuestros, a quien seguía el Cabildo de la ciudad con otros tribunales, la Real Audiencia y señor virrey" (Anua 1639, f. 132r). Era uno de los mayores que habían sido enviados a América. César Baronio se lo había entregado al hermano Juan de Casasola antes de que este viajara al Perú. Según VARgas UGarTe, el "brazo vertical medía unas cuatro pulgadas de largo y el horizontal era en proporción; el grueso de unos cuatro o cinco milímetros" (Los jesuitas, p. 30). 
Y delante dellos iban más de ciento y veinteicuatro sacerdotes y estudiantes y coadjutores hermanos del Callao, de San Martín, Cercado y el Noviciado,

795 todos con sobrepellices, con mucha modestia andando.

Todas las andas cargaban

(si no es las de san Ignacio y lignum crucis, que padres

$800 \quad$ sacerdotes las cargaron)

los hermanos coadjutores, y ciriales y incensarios los hermanos estudiantes fueron los que los llevaron.

805 El señor excelentísimo, que de Chinchón es su estado, virrey y lugartiniente de nuestro monarca Cuarto

(el gran rey de las Españas,

810 que guarde Dios tantos años que a la memoria le falte potencia para contarlos y le aumente su poder por tan dilatado espacio que, dando fin a la tierra, se ponga por epitafio en colunas levantadas que compitan con los astros el nombre plus ultra que diga: "Hasta aquí conquistó el Cuarto

792 coadjutor: "Llaman en la sagrada religión de la Compañía de Jesús a los que no hacen la profesión solemne; y se distinguen llamando coadjutores espirituales a los sacerdotes, y temporales a los que no lo han de ser" (Autoridades).

793 Callao: era el puerto de Lima. La primera iglesia jesuítica del Callao se erigió hacia 1570, y el colegio de la Compañía fue fundado en 1614; San Martín: véase v. 779.

794 Cercado: como recuerda Bernabé Cobo, "El pueblo del Cercado es un barrio de esta ciudad [Lima] en que viven solo indios, con su curato aparte" (Historia, p. 136). Los jesuitas erigieron una iglesia en Santiago del Cercado en 1570, que fue reedificada en 1601. Además, con el apoyo del Príncipe de Esquilache, hacia 1618 se fundó un colegio seminario jesuítico para los hijos de caciques, el Colegio Real del Príncipe; Noviciado: "Otra casa tienen en esta ciudad [Lima] los religiosos de la Compañía de Jesús intitulada San Antonio Abad, que es su noviciado. Fundose el año de mil seicientos seis" (Сово, Historia, p. 274).

805 El señor excelentísimo: Luis Jerónimo Fernández de Cabrera y Bobadilla (1589-1647), conde de Chinchón, que fue virrey del Perú de 1629 a 1639.

809 rey de las Españas: Felipe IV (1605-1655), rey de España de 1621 a 1655.

817 colunas: alude a las legendarias columnas de Hércules (en el estrecho de Gibraltar), que señalaban el fin del mundo conocido en la mitología clásica con el lema "Non plus ultra". Carlos V incluyó las columnas en su escudo de armas con la divisa "Plus ultra", indicando que los españoles las habían superado gracias al descubrimiento de América. 
Filipo, gran rey d'España, y no dio adelante paso, porque le faltó la tierra;

825 escurecida la fama con su grandeza dejando de Jerjes y Viriatos, Saladinos y Pompeyos, de Césares y Alejandros”), iba en el puesto que suele

830 y lugar acostumbrado y toda la Real Audiencia, porque este ilustre senado engrandece y autoriza siempre las fiestas de santos con un religioso celo y con un amor cristiano.

Luego el Tribunal de Cuentas, que son contadores cuatro, el insigne regimiento,

840 sus alcaldes ordinarios, que algunos dellos llevaban todas las varas del palio, y acompañando al virrey caballeros y criados.

845 Fue andando de aquesta forma, en la catredal entrando, donde salió a recebirla el Cabildo Eclesiástico

826-828 Menciona a varios próceres famosos; Jerjes: rey de Persia (siglo v a.C.) que encabezó la Segunda Guerra Médica contra los atenienses; Viriato: caudillo lusitano (siglo II a.C.) que se enfrentó a los romanos en las guerras de Hispania; Saladino: sultán de Egipto y Siria (1138-1193), fue uno de los grandes próceres islámicos en la época de las cruzadas; Pompeyo: líder republicano (106-48 a.C.) en la guerra civil contra Julio César; César: general de la fuerzas romanas (100-44 a.C.), gran conquistador y jefe de las fuerzas rebeldes que vencieron la guerra civil, haciéndose con el poder en Roma; Alejandro: conocido como el Magno (356-323 a.C.), rey de Macedonia, dueño de un gran imperio que se extendía hasta la India.

831 Real Audiencia: tribunal y órgano central del poder imperial en Lima, cuya composición se detalla en la Descripción de León Portocarrero: "En la Chansellería o Audiencia Real de Lima asisten cuando menos ocho oidores, cuatro alcaldes de corte, dos fiscales (uno del crimen, otro del civil), secretarios, relatores y todos los demás oficios pertenecientes. Preside en los negocios más importantes el visorrey" (p. 33). Сово indica que tenía dos "grandes preeminencias": "la facultad que le ha dado su majestad para que por muerte o grave enfermedad del virrey ella sola tenga la gobernación de todo el reino" y "tener facultad para que en ella puedan pedir su justicia los que se sintieren agraviados de las cosas que proveyese el virrey" (Historia, p. 112).

837 Tribunal de Cuentas: compuesto por contadores mayores, menores y de resultas, además de otros cargos secundarios. Sus miembros se encargaban de regular la hacienda real: "Tienen poder y facultad de tomar y fenecer las cuentas que en cualquiera manera y por cualquier causa y razón pertenecen a la real hacienda" (Сово, Historia, p. 122).

848 Cabildo Eclesiástico: "La junta que tienen y celebran los canónigos y prebendados de las iglesias catedrales" (Autoridades). 
al tiempo que emparejaba

el glorioso san Ignacio, poniéndose en procesión todo el clero, el preste dando lugar al lado derecho al provincial, que de Ignacio

855 es hijo y su religión está agora gobernando.

Los clérigos se pusieron todos al derecho lado y los de la Compañía

$860 \quad$ al izquierdo se pasaron.

En este tiempo ya estaba debajo del palio blanco, donde el lignum crucis iba, Cristo Dios sacramentado, 865 que en una custodia aquesto, sobre unas andas que un arco de diversidad de flores adornaba con agrado, habían tenido puesto

870 con mucha cera alumbrando y olores en cazoletas por un espacioso rato.

La procesión se aumentó

875 porque los clérigos eran más de ducientos y tantos, porque no quedó ninguno que no fuese convidado del Cabildo de la iglesia

$880 \quad$ y por su grave arcediano. La música de la iglesia iba en su tropa cantando motetes y chanzonetas

885 Las cruces de las parroquias, mayordomos, diputados de todas las cofradías que los cetros en las manos

854 al provincial: véase el v. 317.

845-856 Compárese con Anua 1639: "nos salió a recebir el Cabildo Eclesiástico con toda la clerecía, a quienes cedimos la mano derecha de la procesión” (f. 132r).

871 cazoleta: "Especie de perfume a quien se da este nombre, porque se pone para quemarle en un vaso semejante a una cazuela pequeña" (Autoridades).

880 su grave arcediano: véase el v. 389.

883 motete: "Breve composición música para cantar en las iglesias que, regularmente, se forma sobre algunas cláusulas de la Escritura" (Autoridades); chanzoneta: "Letrilla, villancico o tono festivo y de regocijo para cantar en alguna festividad" (Autoridades). 


$\begin{array}{cl}\text { 890 } & \text { llevaban algunos dellos } \\ \text { y otros estandartes tantos } \\ \text { que, si no conté mal, eran } \\ \text { todos más de treinta y cuatro. } \\ \text { Ya delante se habían puesto } \\ \text { compañías de soldados } \\ \text { que en concierto militar } \\ \text { iban todos disparando, } \\ \text { cajas, clarines, trompetas } \\ \text { en puestos acomodados } \\ \text { y ternos de cheremías } \\ \text { que algunos iban tocando. } \\ \text { La tarasca y los gigantes, } \\ \text { regocijo de muchachos, } \\ \text { iban delante también } \\ \text { a lo gigante bailando, } \\ \text { algunas danzas d'espadas } \\ \text { que hacían el toqueado } \\ \text { y otras que también lo hacen } \\ \text { con broquelillos y palos. } \\ \text { Muchos negros con tambores } \\ \text { iban tañendo y cantando, } \\ \text { indios y indias que bailaban } \\ \text { la gaita a lo zamorano. } \\ \text { Muchos caballeros iban } \\ \text { en puestos no señalados, } \\ \text { nobles hidalgos y pueblo } \\ \text { en concurso acompañando. } \\ \text { Fue pasando por la plaza } \\ \text { y a un lado estaba arrimado } \\ \text { un grande y curioso altar } \\ \text { que había tomado a su cargo }\end{array}$

897 caja: "Se llama también el tambor, especialmente entre los soldados" (Autoridades). 899 cheremía ('chirimía'): "Instrumento músico de madera encañonado a modo de trompeta, derecho, sin vuelta alguna, largo de tres cuartas, con diez agujeros para el uso de los dedos con los cuales se forma la armonía del sonido según sale el aire" (Autoridades).

893-900 Compárese con Relación succinta: "los recibió la infantería española que asiste en esta ciudad con salva y mosquetería, tremolando y abatiendo las banderas con gala y bizarría" (f. $\left.2^{\mathrm{r}}\right)$.

901 tarasca: "Una sierpe contrahecha que suelen sacar en algunas fiestas de regocijo" (Covarrubias).

905 danzas d'espadas: "Se llama la que se ordena con espadas en la mano, con las cuales, al compás de los instrumentos, se dan algunos golpes" (Autoridades).

906 toqueado: 'son o golpeo acorde'.

908 broquelillo: diminutivo de broquel: "Arma defensiva, especie de rodela o escudo redondo hecho de madera" (Autoridades). 
Julián Santos de Saldaña, que es afecto aficionado a toda la Compañía, y fue desde allí pasando a la calle de las Mantas. $Y$ al principio della abajo estaba la religión de aquel africano santo, el mayor de los doctores

930 y el maestro de los sabios, que con su padre Agustino y otros seis u siete santos de su religión sagrada con un religioso aplauso

935 salieron en procesión y recibieron a Ignacio.

Y con santas cortesías inclinaron a los santos, dándole el lado derecho

$940 \quad$ Agustino a san Ignacio.

Y también lo mismo hicieron unos santos a otros santos, cargando los de Agustino al glorioso san Ignacio

945 y los de la Compañía a san Agustín cargaron, porque estas dos religiones de Agustino y la de Ignacio están hoy con tanta unión 950 y sus hijos tan hermanos que hoy el hijo de Agustino es también hijo de Ignacio y el de Ignacio de Agustino y todos d'entrambos santos,

921 Julián Santos de Saldaña: "vecino e impresor de libros de la Ciudad de los Reyes", como se lee en una cédula real de 1652. Su imprenta ya funcionaba en 1638. "Fue el taller que ocuparon de ordinario los agustinos, y de sus prensas salieron algunos de los libros limeños más raros que hoy se conocen” según José Toribio Medina, La imprenta en Lima (1584-1824), Impreso y grabado en casa del autor, Santiago de Chile, 1904-1907, t. 1, pp. xlv-xlvi y 450.

925 las Mantas: calle céntrica de Lima "llena de tiendas de mercaderes" (León PortocARREro, Descripción, p. 61). Entre ellas, predominaban "los establecimientos donde se vendían mantas o ropa de la tierra, como se decía a las prendas de vestir que se hacían en el país y que usaban sus naturales" (JuAn Bromley, Las viejas calles de Lima, Gerencia de Educación, Cultura y Deportes/Edilibros, Lima, 2005, p. 227).

928 africano santo: san Agustín, nacido en Tagaste (hoy Souk Ahras, en Argelia).

939 dándole el lado derecho: "aquí se levantó una humilde porfía que edificó a tanta gente como había de fuera y desta corte sobre cuál de los dos patrones, san Augustín o san Ignacio, que ya esta [había], había de llevar la mano derecha, pretendiendo la izquierda todos con tantas cortesías, razones e instancias" (Anua 1639, f. 132 ). 


\begin{tabular}{|c|c|}
\hline \multirow[t]{2}{*}{955} & que este vínculo de amor \\
\hline & $\begin{array}{l}\text { por todos se ha profesado. } \\
\text { Treinta de los agustinos, } \\
\text { con sus hachas en las manos }\end{array}$ \\
\hline \multirow[t]{2}{*}{960} & $\begin{array}{l}\text { y casullas y albas puestas } \\
\text { de telas y de damascos, } \\
\text { y los demás con sus velas }\end{array}$ \\
\hline & iban todos alumbrando, \\
\hline \multirow{5}{*}{965} & llevando el lado derecho \\
\hline & los hijos de san Ignacio. \\
\hline & Prosiguió la procesión \\
\hline & por la calle, atravesando \\
\hline & a la de san Agustín, \\
\hline \multirow{4}{*}{970} & $\begin{array}{l}\text { y por una puerta entrando } \\
\text { de su iglesia; por la otra }\end{array}$ \\
\hline & fue la salida y el paso, \\
\hline & siempre el órgano tañendo \\
\hline & y la música cantando. \\
\hline \multirow{4}{*}{975} & En medio la iglesia estaba \\
\hline & un rico altar fabricado, \\
\hline & y el asiento y pie cuadrado. \\
\hline & Su altura de veinte varas \\
\hline \multirow{3}{*}{980} & y por cumbre un tabernáculo \\
\hline & $\begin{array}{l}\text { donde la Virgen y madre } \\
\text { tenía a los pies a Ignacio. }\end{array}$ \\
\hline & Y todo de nuevo hecho, \\
\hline \multirow{5}{*}{985} & $\begin{array}{l}\text { que no fue allí acomodado, } \\
\text { porque ello mismo decía }\end{array}$ \\
\hline & que se hizo para el caso. \\
\hline & Todo estaba muy curioso \\
\hline & y muy bien acomodado, \\
\hline & con igual correspondencia \\
\hline & sus cuatro vistas y lados. \\
\hline & \\
\hline & los dos que quedan nombrados \\
\hline & en los puestos que declaro. \\
\hline
\end{tabular}

957 Treinta de los agustinos: "y allí empezó el recebimiento que la orden del gran padre Agustino hizo a la Compañía con docientos hijos del santo patriarca y treinta sacerdotes revestidos" (Relación succinta, f. $2^{\mathrm{r}}$ ).

959 casulla: "La última vestidura que se pone el sacerdote sobre todas las otras, con que se adorna y viste para celebrar el santo sacrificio de la misa" (Autoridades); alba: "túnica de lienzo blanco, que sobre su hábito clerical o religioso se ponen después del amito los sacerdotes y ordenados de mayores órdenes para celebrar el santo sacrificio de la misa" (Autoridades).

973-976 Compárese con Relación succinta: "en el cuerpo dél [templo] levantaron un altar triangulado de talla y bultos hermosísimos" (f. $2^{\mathrm{r}}$ ).

982 acomodado: el altar no fue un 'arreglo' de piezas ya existentes, sino que se fabricó especialmente para este evento ("se hizo para el caso"). 
Valladolid hizo uno

la calle de Manta abajo,

995 que su aderezo y riqueza

causó admiración y espanto.

Y fue tanto lo que tuvo

de láminas y de cuadros

y de otras cosas curiosas

1000 que en ellas tiene ocupado

valor con que fueran ricos

más de dos hombres honrados,

y todo es para la fiesta

del Corpus y de los santos.

$1005 \quad$ Otro hicieron los plateros

en la Platería a un lado

con curiosidad y traza,

porque son muy esmerados

y que en todas ocasiones

1010 son los que en públicos actos

con gran liberalidad

gastan en fiestas de santos.

El postrer altar me queda

que alabar: ya no hallo

1015 ningún modo de alabanza,

porque se me han acabado.

Digo que este fue un altar, altar que estuvo arrimado a la cuadra como van

1020 a la Compañía entrando;

altar que fue buen altar, altar que fue muy honrado, altar que fue muy curioso, altar que en él hubo santos...

1025 Los altares me han tenido

demasiado embarazado, que han hecho quebrar el hilo

y que en silencio haya estado

993 Valladolid: en la calle de Juan Ramírez (luego conocida como de Valladolid), que seguía a la de las Mantas, "tenía a principios del siglo XviI un establecimiento de confitería y cerería Pedro de Valladolid y Florín, que dio nombre definitivo a la calle" (BRomLey, Las viejas calles, p. 316). Quizás el poema aluda al hijo de Pedro como patrocinador del altar: Sebastián de Valladolid (nacido en 1568), maestro cerero como su padre.

993-996 Compárese con Relación succinta: "al entrar en la calle que llaman de las Mantas, cuyo testero se cerró con un vistoso y rico altar" (f. $2^{r}$ ).

1000 ocupado: 'invertido'.

1005 los plateros: la calle de los Plateros, o Platería de los Plateros, hacía esquina con la de las Mantas. Aquí se asentaban los talleres de los plateros de oro y plata, que formaban uno de los gremios más antiguos e influyentes de Lima (Bromley, Las viejas calles, pp. 269-270).

1019 cuadra: 'manzana, espacio entre dos esquinas en una manzana' (americanismo). 
la procesión... Allá vuelvo, que ha mucho que della falto, que estos altares han sido causa de haberla dejado.

Subió por la Platería y vino a dar fin entrando

1035 en el nuevo templo, adonde se acabó a las seis y cuarto.

Todas las calles colgadas de telas y de damascos y otras sedas diferentes,

1040 desde abajo a los terrados.

Muchas damas en balcones, en ventanas y en escaños, que por mostrar perros muertos no usaban de los tapados.

1045 Gran concurso por las calles y, con ser en tanto grado, hubo en todos compostura, que se tuvo por milagro.

Hubo arcos de muchas flores

1050 y muchos cuadros colgados, muchos cohetes, clarines, repiques en campanarios.

No entraron al templo todos, porque no cupieron tantos,

1055 aunque es grande, por ser muchos todos los que se juntaron.

Estaba dentro hecho un cielo sus altares y retablos, costosamente lucidos,

1060 curiosamente adornados.

Todos los santos pusieron en sus puestos dedicados y junto al altar mayor a san Agustín y a Ignacio.

1065 Agustino el lado tuvo derecho, que tan honrado güésped no había de ser menos honrado de Ignacio.

1043 perro muerto: quiere decir ir con una prostituta y no pagarle, pero se usaba también con el sentido más general de 'treta, engaño' (José Luis Alonso Hernández, Léxico del marginalismo del Siglo de Oro, Universidad, Salamanca, 1977, p. 605).

1044 los tapados: las mujeres solían 'taparse' como medio de seducción para intrigar a sus posibles pretendientes. La tapada es un personaje típico de la sátira de la época, y solía asociarse con la prostitución (Alonso Hernández, Léxico, p. 726). En este caso, las damas más coquetas de Lima no se tapan, incitando sexualmente a los hombres.

1057 hecho un cielo: "Frase metafórica con que se expresa que algún templo u otro sitio está muy devoto, suave, ameno u delicioso" (Autoridades). 
Los siete santos sus hijos

1075

a su iglesia los tornaron

en forma de procesión

y los llevaron cargados

padres de la Compañía

con chirimías y cantos,

y los hijos de Agustino

en su iglesia colocaron

el sanctísimo. Quedó

en su sagrario encerrado,

lo cual antes se había hecho

1080 que se llevaran los santos.

Llegada que fue la noche

y puesto su negro manto

se comenzaron los fuegos,

que había muchos preparados.

1085 Castillos, sierpes, galeras,

elefantes, naves, barcos,

bombas, ruedas, esmeriles,

voladores por lo alto

y buscapiés por el suelo

1090 que alborotaban muchachos, centelleros, serpentinos

y un castillo tan cargado

de diferencia de fuegos

que duró por grande rato

1095 y fue el mejor que se ha visto

en Lima en algunos años.

A este castillo dio fuego

una nao, que de lo alto

por un cordel la traían,

1100 como que le daba asalto.

1083 los fuegos: "a la noche hubo muchos y muy grandes fuegos y luminarias" (SuARdo, Diario, t. 2, p. 187); "se empezaron los fuegos..., fueron tan costosos, tan exquisitos y admirables que dellos solos se hará una relación aparte. Y con las músicas, juegos de flautas y chirimías, repiques de campanas, luminarias, fuegos de todas las torres de los templos se halló esta noche en una alegre y apacible confusión toda esta ciudad" (Relación succinta, ff. $2^{\mathrm{r}}-2^{\mathrm{v}}$ ); "se comenzaron los fuegos, a que aguardaba la señora virreina, que fueron muy vistosos, de castillos, naos y gigantes, con que se dio fin a este día" (Anua 1639, f. 132v).

1087 bomba: "Máquina militar hecha de hierro colado redonda y hueca, de diferentes tamaños, la cual se llena de pólvora por un agujero" (Autoridades); esmeril: "pieza de artillería pequeña, algo mayor que la que se dice falconete" (Autoridades).

1088 voladores: "Se aplica también a algunos ingenios y artificios de fuego, que se disparan al aire, subiendo muy altos" (Autoridades).

1089 buscapiés: "Un cohete que, porque encendido se arroja a tierra y con el viento que hacen los que huyen los sigue más, se llama asî" (Autoridades). 
En una torre se puso

un gigantazo tan alto

que parecía un Polifemo

u algún peñasco empinado,

1105 con gran cargazón de fuego

por todo el cuerpo sembrado

y el brazo derecho estaba

con una maza en la mano.

Por ella quisieron darle

1110 el fuego, y tardose tanto

que dio a todos a entender

que estaba muy enfadado

de que a gigante como él

l'encendiesen por el brazo:

1115 y así no quiso admetirlo, por más que se lo rogaron.

Mas el que le daba fuego

se vio dél tan enfadado

que se le vino a pegar

1120 por uno de los zancajos,

y él, sintiendo la traición,

soltó de sí tantos rayos

que el Paladión de Troya

no vomitó más soldados

1125 para abrasar la ciudad

ni hicieron ruido tanto

como hicieron sus cohetes,

bombas, ruedas, cañonazos

y otras muchas diferencias

1130 de que estaba el cuerpo hipado;

y fue eficaz medecina

el fuego con que le untaron.

Todas las torres y templo

por en medio y por lo alto

1135 estaban con luminarias,

con los papeles pintados

1103 Polifemo: cíclope gigantesco de la mitología clásica que aparece en obras como la Odisea de Homero y las Metamorfosis de Ovidio. Luis DE Góngora le dedicó uno de sus poemas más famosos: El Polifemo (1612). De hecho, la comparación con un peñasco parece evocar esta obra: el cíclope habita en una gruta donde un "peñasco" le sirve de puerta, y la misma figura de Polifemo se equipara a un monte: "Un monte era de miembros eminente" (Fábula de Polifemo y Galatea, ed. Jesús Ponce Cárdenas, Cátedra, Madrid, 2010, vv. 48-49).

1115 admetirlo: 'permitirlo'.

1120 zancajo: 'pierna'.

1123 Paladión de Troya: monumental caballo de madera que, según la leyenda, decidió las suertes de la guerra de Troya. Los griegos engañaron a los troyanos ocultándose en este caballo, que fue llevado dentro de los muros de la ciudad. Por la noche salieron de él y derrotaron fácilmente a sus enemigos, tomados por sorpresa.

1130 hipado: 'harto, ahíto'. 
de colorado y azul, que con la luz animados

1140 daban visos de topacio que recreaban la vista; $y$, por estar graduados, desde lejos parecía un munumento formado.

$1145 \quad$ Llena la plazuela estaba de candeladas y hachos; chirimías y clarines se tocaban en lo alto.

Cajas, pífanos, cohetes, 1150 repiques y campanazos, bombas, ruedas, esmeriles y ruido de muchachos: todo junto parecían ejércitos encontrados 1155 dándose guerra en campaña $\mathrm{u}$ en batalla de Lepanto.

Los agustinos también a su torre la llenaron de luminarias, haciendo

1160 candeladas en lo bajo; ni de repicar campanas en mucho tiempo cesaron, tanto que en la vecindad casi estaban enfadados.

1165 Los señores del Cabildo Secular también mandaron se pusiesen luminarias en él por todos sus altos,

de donde muchos cohetes

1170 y ruedas se dispararon; y a las torres de la iglesia y cornisas ocupando de lo mismo y las campanas diestramente repicaron,

1146 candeladas: "La multitud de luces o luminarias que arden a un tiempo en alguna ciudad o sitio" (Autoridades); hacho (o hachón): "Cierto género de hacha que se hace de esparto y carrizos, cubierta con pez, la cual sirve para alumbrarse por las calles y caminos las noches tenebrosas y obscuras, y también sirve para luminarias en las festividades" (Autoridades).

1149 pifano: "Instrumento militar bien conocido, que sirve en la infantería acompañado con la caja. Es una pequeña flauta, de muy sonora y aguda voz, que se toca atravesada” (Autoridades). Acerca de caja, véase el v. 897.

1156 Lepanto: la batalla naval de Lepanto (1571) supuso una de las victorias militares más memorables de las fuerzas hispanas, en una Liga Santa con otras naciones, contra el imperio otomano.

1165-1166 Cabildo Secular: ayuntamiento de Lima, formado por dos alcaldes ordinarios, varios regidores y otros jueces, contadores y escribanos. 
1175 que otra fiesta de por sí

en la plaza hacían al santo.

Hogueras y luminarias

hubo en otros muchos barrios

de casas particulares

1180 devotos de san Ignacio.

Acabáronse los fuegos

y yo d'escrebir acabo

lo que en este día y noche

se ha hecho y se ha festejado.

1185 Luego el sábado, que fue

el día de san Ignacio,

al amanecer había

muchísimos aguardando

a que se abriese la iglesia

$1190 \quad$ y gran número d'escaños

que llevaban muchos negros

para asiento de sus amos.

También llevaron las negras

para sus amas estrados,

1195 que esta prevención hacían

aunque es el templo muy largo.

Acudió tan gran concurso

que, si fuera otros dos tantos,

1200 para todo limitado.

también entiendo que fuera

Hecho un cielo estaba todo:

los santos acomodados

y todos gozaban dellos

con devoción y descanso.

1205 Muchos olores había

de los finos, no ordinarios,

en cazoletas y pomos

y toros agarrochados

con garrochas de pebetes

1210

en su fragancia estremados;

porque descubierto estaba

Cristo Dios sacramentado

1194 estrado: "el lugar donde las señoras se asientan sobre cojines y reciben las visitas" (Covarrubias).

1198 si fuera otros dos tantos: 'si el templo fuera dos veces más grande'.

1201 Hecho un cielo: véase el v. 1057.

1207 cazoleta: véase el v. 871; pomo: "el vaso de vidro de hechura de una manzana que sirve para tener y conservar los licuores o confecciones olorosas" (Autoridades).

1208 agarrochado: 'herido de garrocha'. Obviamente, se trata de toros decorativos y no de carne y hueso.

1209 garrocha: "Vara larga y delgada que en la extremidad más gruesa tiene un hierro pequeño con un arponcillo para que no se desprenda" (Autoridades); pebete: "vírgula aromática conficionada de polvos odoríferos que, encendida, echa de sí un humo odorífero" (Covarrubias). 
y lo estuvo todo el día haciendo corte y estado,

1215 merced y misericordia a todo el pueblo cristiano.

Riquísimos ornamentos de altares y vestuarios, albas, manteles, roquetes,

1220 con primor encarrujados.

Porque el sacristán que tienen

es en todo aventajado,

solícito y cuidadoso

y curioso en sumo grado,

1225 y así en esta, como en todas

las fiestas que hay entre año,

es quien lo más de su adorno

toma a su cuidado y cargo.

Y haber los santos salido

1230 todos tan aderezados

a él se debe lo más,

porque lo ha solicitado.

Estuvo la portería

hecho un templo abreviado,

1235 que la tuvo muy curiosa

el que la tiene a su cargo:

colgada de ricas telas

y de láminas y cuadros

y con varia poesía

1240 en alabanza del santo.

Virrey y Audiencia vinieron

y el Cabildo Eclesiástico,

el Secular, contadores,

que ya he dicho que son cuatro.

1245

También el ilustrísimo

obispo de Santiago y

de Chile, que es de Agustino

y también lo es de Ignacio,

1219 alba: véase el v. 959; roquete: "Vestidura de holanda o otra tela delgada de que los obispos y prelados usan sobre la sotana" (Covarrubias).

1220 encarrujado: "Ensortijado, retorcido" (Autoridades).

1224 curioso: "Aseado, primoroso, esmerado en la ejecución de las cosas" (Autoridades).

1232 lo ha solicitado: 'lo ha procurado, se ha encargado de ello'.

1241 Virrey y Audiencia vinieron: "Vino el señor virrey y Real Audiencia" (Anua 1639, f. 132v). 1244 cuatro: véase el v. 838.

1246 obispo de Santiago: el agustino Gaspar de Villarroel, nacido en Quito en 1587, realizó sus estudios de teología en la Universidad de San Marcos de Lima. Fue elegido obispo de Santiago de Chile en 1637 y, luego, obispo de Arequipa (1651) y La Plata (1660), donde falleció en 1665. Véase el v. 190. 
1250 mayor al derecho lado y el virrey y los demás en sus puestos señalados.

El Cabildo de la iglesia tuvo coro preparado

1255 y se asentaron en sillas; los escaños ocuparon padres de la Compañía y el provincial tuvo el lado del deán, que también hoy 1260 quisieron de nuevo honrallo.

También otros padres hubo de los graves, que asentados entre ellos lugar tuvieron, cuyo nombre no señalo.

$1265 \quad$ Frailes agustinos hubo y del seráfico sancto que de la misma manera los asientos ocuparon.

Los señores ilustrísimos, 1270 que del tribunal más santo son dignos inquisidores, en la tribuna de un lado de las del altar mayor estuvieron asentados, 1275 aunque por su autoridad las celosías echaron.

$\mathrm{Y}$ de la misma manera también habían estado al pasar la procesión, 1280 que de un balcón miraron.

A las diez se comenzó la misa, que la oficiaron los cantores de la iglesia, que son muy aventajados,

1249 estuvo junto al altar: "al fin de la misa echó la bendición el reverendísimo obispo de Santiago de Chile, que asistió este día al lado del altar mayor" (Relación succinta, f. $2^{\mathrm{v}}$ ).

1258 provincial: véase el v. 317.

1259 deán: el padre maestro Domingo de Almeida. Natural de Sevilla, pasó a América en 1580 como capellán doméstico del recién electo arzobispo de Lima, Toribio de Mogrovejo. Fue deán de la catedral de Lima desde 1619. Falleció a la edad de 91 años en 1645 (Mendiburu, t. 1, p. 168).

1266 seráfico sancto: san Francisco; seráfico: "Lo que pertenece o se parece al serafín. Suele darse este epíteto a S. Francisco de Asís y a su sagrada religión" (Autoridades).

1270 tribunal más santo: el Tribunal de la Santa Inquisición, establecido en Lima en 1570. Como indica Сово: "Los ministros ordinarios que tiene son: dos inquisidores (sin embargo que de presente son cuatro), un fiscal, secretario del secreto, a mil pesos ensayados de salario cada uno, un notario de los secretos con seiscientos, alguacil mayor mil, un rector otros mil, un contador doscientos, alcaide quinientos, un nuncio con cuatrocientos corrientes" (Historia, p. 227). 
1285 dijo: 'dijo misa', pues esta era una de las acepciones de decir: "Se toma también por orar y predicar" (Autoridades); doctor Ortega: Pedro de Ortega Sotomayor, nacido en Lima en 1565, ganó a la edad de diez y nueve años la cátedra de Artes en la Universidad de San Marcos y luego, sucesivamente, la de vísperas y la de prima de teología. Fue rector de la Universidad, calificador del Santo Oficio, maestrescuela y arcediano de Lima. En 1644 fue elegido obispo de Trujillo, pero tomó posesión solo en 1647, el mismo año en que se le concedió el obispado de Arequipa. En 1652 tomó cargo como obispo de Cusco. Falleció el 7 de agosto de 1658 (Mendiburu, t. 6, pp. 186-188; SuARdo, Diario, t. 1, pp. 11-12, n. 1). Compárese con Relación succinta: "la misa que decía el señor maestrescuela de la santa iglesia" (f. $2^{v}$ ); Anua 1639: "cantó la misa la música de la catedral, y díjola el señor maestrescuela" (f. 132 $2^{\mathrm{v}}$ ).

1286-1287 catedrático de prima: las cátedras se dividían según el tiempo en el que se impartían las clases, lo cual implicaba mayor o menor prestigio, como indica Autoridades: "así se llama cátedra de prima la de la mañana, de vísperas la de la tarde; y conforme a esto tienen su graduación y mayoría, siendo la de prima la de mayor estimación".

1287 sujeto: "persona de especial calidad o prendas" (Autoridades).

1290 el comisario arcediano: véase el v. 389. Compárese con Medrano: "predicó el Dr. Bartolomé de Benavides, arcediano desta santa iglesia, comisario general de la Santa Cruzada" (SuARdo, Diario, t. 2, p. 188); "Predicó el señor doctor don Bartolomé de Benavides, comisario general de la Cruzada, excelentemente como suele" (Anua 1639, f. 132").

1293 y a queda hecho: véase el v. 390.

1301 Crisóstomo: Juan Crisóstomo (347-407), patriarca de Constantinopla y Padre de la Iglesia, orador aventajado, lo cual le valió su apodo de Crisóstomo (literalmente, 'Boca de oro'). 
1315 no ostentado ni pomposo, crítico ni cultomaco, el sermón mejor ha sido que hasta hoy vi predicado 1320 a festividad del santo.

Dicen que se ha d'imprimir: digno es de ser estampado. Si se hiciese, yo os prometo d'enviaros dél un tanto.

1325 Y sé que, si os l'enviare y llegase a vuestras manos, veréis que en lo que aquí digo no queda bien ponderado.

Misa y sermón se acabó

1330 y allá a las tres o las cuatro hubo vísperas solemnes.

Y después que se acabaron encerraron al Señor 1335 que en un trono y sitial poniéndole en el sagrario, hasta entonces había estado.

Y antes que más tarde fuese dispusieron y ordenaron

$1340 \quad$ todos los padres y hermanos y en procesión muy solemne, acompañándole Ignacio, los padres más graves fueron quien lo llevaron cargados. Ignacio llevó Agustino, puesto a su derecho lado,

1316 cultomaco: ataque al estilo culto que, inspirándose en las obras de Luis de Góngora, se había generalizado en la poesía y en la oratoria sagrada del siglo Xvir. Uno de sus seguidores y representantes más importantes fue el trinitario Hortensio Félix Paravicino (1580-1633).

1321 se ha d'imprimir: se publicó al año siguiente, Sermón en la dedicación del nuevo y famoso templo de San Pablo de la Compañia de Jesús de Lima, en el día del glorioso patriarca san Ignacio, Jerónimo de Contreras, Lima, 1639.

1324 tanto: "la copia o ejemplar que se da de algún escrito, trasladado de su original" (Autoridades).

1329-1331 Compárese con Relación succinta: "se acabaron los oficios, hasta las tres de la tarde, que se empezaron las vísperas solemnísimas” (f. $2^{\mathrm{v}}$ ).

1335 sitial: "El asiento o silla con un pequeño banco delante, cubierto de un tapete con una almohada o cojín encima y otra a los pies de la silla, de que usan los reyes, príncipes y prelados en la asistencia de las funciones públicas" (Autoridades).

1344 quien: 'quienes'. Antes del siglo Xvi el pronombre relativo quien era invariable para singular y plural; el uso del plural analógico quienes tardó en generalizarse en castellano. Véase RAFAel LAPESA, Historia de la lengua española, Gredos, Madrid, 1988, pp. 397-398.

1345 llevó Agustino: la falta de la preposición a ante acusativo de persona (Agustino) podría ser un error de copia, o también un ejemplo de vacilación, pues su uso todavía no se había fijado en el español del siglo Xvir. Véase LAPESA, p. 405. Hay casos semejantes en los vv. 1349 y 1353. 
hasta dejarlo en su iglesia en su altar ya colocado,

1350

pagando Ignacio Agustino

el haberle acompañado y dado el lado derecho, que son cortesanos santos.

Recibieron Agustino sus hijos y con Ignacio

1355 vinieron en procesión, de aqueste modo pagando unos a otros cortesías hechas con estos dos santos. Y lo que hubo en este día 1360 en lo dicho se ha cifrado.

A la noche hubo cohetes, triquitraques arrojados y otros que por un cordel sin alas iban volando.

1365 Muy gran número de ruedas, que por el cordel echaron, candeladas, chirimías y clarines en lo alto y repique de campanas

1370 que las hacían pedazos hasta que los tañedores las dejaron de cansados.

También el día siguiente, domingo después del santo,

1375 dijeron sermón y misa entre los hijos de Ignacio, aunque la música fue de agustinos, que cantaron de milagro, porque son los más sonoros en canto.

Predicó un padre muy docto, no quiso alabar el santo ni la fiesta: solo dijo del rico y el publicano

1357 cortesías: "la esclarecida Orden de San Agustín... a la tarde se volvió a su casa, acompañados hasta ella de los hijos de Ignacio, compitiendo todos y venciendo ninguno en cortesías" (Relación succinta, f. 2v); "cargaron los nuestros sus andas y volvimos acompañándoles a su casa" (Anua 1639, f. 132 $2^{\mathrm{v}}$. Hay una discrepancia cronológica en las fuentes: según Anua 1639 esta procesión de los agustinos de regreso a su templo tuvo lugar el viernes 30 de julio, según la Carta, el sábado 31 de julio, mientras que para la Relación succinta fue el domingo 1 de agosto. nación.

1362 triquitraque: rollo de papel con pólvora que, encendido, produce una pequeña deto-

1367 candeladas: véase el v. 1146.

1373 el día siguiente: domingo 1 de agosto de 1638.

1381 un padre muy docto: las fuentes no indican quién era.

1384 del rico y el publicano: parece aludir a las parábolas del rico y el pobre Lázaro (Lucas 16: 19-31), y la del fariseo y el publicano (Lucas 18: 9-14). 
1385 todo lo que dicho hubo, si no es que me haya dejado algo por decir, que otro lo dirá mejor cantando.

Ha sido la mejor fiesta

1390 que en Lima se ha celebrado y es general opinión en todos, mozos y ancianos:

más rica, más suntuosa,

1395 de más acompañamiento, de más santos adornados, más religiosa y devota y de más eclesiásticos, pues solos clérigos eran

1400 más de ducientos y tantos; de más ciudadanos nobles, de más caballeros de hábito y de más pueblo común, de más adorno colgado,

1405 de más quietud, sin que en ella ninguno haya pendenciado, y tal que todos a una, unánimes y concertados, decían: "La Compañía

1410 pocas fiestas hace y cuando hace alguna lleva siempre de todas la palma y lauro".

Y hace mayor su grandeza

1415 su excelencia la virreina, que, dejando su palacio con su excelencia el virrey y el sucesor de su estado, antes de la procesión

$1420 \quad$ entraron a ver los santos que en el templo viejo a todos tenían aderezados y admiroles la riqueza que en ellos se había juntado.

1415 la virreina: Francisca Enríquez de Rivera, segunda esposa del conde de Chinchón y virreina del Perú. Falleció en Cartagena de Indias en 1641.

1418 el sucesor de su estado: Francisco Fausto Fernández de Cabrera y Bobadilla (1629-1665), hijo de los virreyes. Fue marqués de San Martín de la Vega y, tras la muerte de su padre, le sucedió como V conde de Chinchón. 
1425 De allí pasaron a ver

el templo nuevo y el paso;

que no entrase nadie entonces

impidieron los soldados

de la guarda, para que

1430 sin ruido ni embarazo

pudiesen gozar de todo.

$Y$ de nuevo se admiraron

de ver cuán perfectamente

estaba el templo acabado

1435 y curiosamente puesta

la riqueza de su ornato.

Habiendo ya visto el templo,

su grandeza y aparato,

en una casa frontero

1440 del señor ya jubilado

oidor de la Real Audiencia

entraron, de allí mirando

su excelencia la virreina

y el marqués, su mayorazgo,

1445 la procesión. Y el virrey,

después que se hubo acabado,

se subió al mismo balcón

y juntos los tres gustaron

de ver desde allí los fuegos;

1450 y después que se acabaron

se entraron en su carroza

$\mathrm{y}$ volvieron a palacio.

Y ser la fiesta más grave

que en Lima se ha celebrado

1455 y la de mayor grandeza

muy bien queda averiguado.

Pues, ¿cuándo se ha visto en Lima,

después que el marqués Pizarro

la conquistó, que virreinas

1460 hayan dejado el palacio

y visto las procesiones,

si no ha sido la de Ignacio,

1441 oidor de la Real Audiencia: Luis Merlo de la Fuente, natural de Valdepeñas, que pasó a América en 1588, donde ejerció varios cargos oficiales, como el de gobernador y capitán general de Chile. Fue oidor de la Real Audiencia de Lima desde 1606 hasta su jubilación en 1618. Falleció el 10 de octubre de 1638 (Guillermo Lohmann Villena, Los ministros de la Audiencia de Lima en el reinado de los Borbones (1700-1821), Escuela de Estudios Hispano-Americanos de Sevilla-CSIC, Sevilla, 1974, pp. 181-182). Compárese con Medrano: "fue la señora virreina y marqués, su hijo, a casa del oidor Merlo de la Fuente, desde donde la vio pasar y los fuegos a la noche" (SuARDo, Diario, t. 2, p. 188).

1444 el marqués, su mayorazgo: véase el v. 1418.

1458 el marqués Pizarro: Francisco Pizarro (1478-1541), conquistador del Perú y fundador de la Ciudad de los Reyes (Lima) en 1535. En 1539 recibió el título de marqués de la Conquista. 
que con devoción y celo así quiso honrar al santo?

1465 Pérdida ninguna hubo, con ser tanto el aparato, tantas joyas, tanto adorno prestado para los santos.

Un diamantillo saltó

1470 de una joya a san Ignacio y habiendo caído al suelo le vino hallar un muchacho, y este a otro se lo dio 1475 que dicen fue un bizcochuelo; y desta suerte, pasando a otro, le dio un real, y el padre deste, mirando que era diamante, advirtió 1480 que podía ser del santo y adonde se aderezó lo llevó y quedó ajustado en su presa: y fue sin duda milagro de san Ignacio.

$1485 \quad$ Una señora llevaba de oro al cuello colgando una cadena y salía por uno de los dos lados, y con la mucha apretura, 1490 habiéndose descuidado, con muy grande sutileza le cortaron un pedazo.

Y, habiendo dicho el subceso

1495 a uno de la Compañía, llevó una negra el pedazo de la cadena a vender a un platero, y echó mano 1500 que adónde le había hurtado. Huyó sin darle respuesta y se lo dejó en la mano, y, entendiendo podía ser haberlo hurtado a algún santo,

1505 dio cuenta en la Compañía de lo que le había pasado; con que por este camino la mujer halló el pedazo de su cadena y se vio 1510 que, sin duda, haberlo hallado no pudo otra cosa ser 
sino milagro del santo.

Otro milagro mayor

que los dichos ha hecho el santo,

1515 pues, siendo yo tan inútil,

ignorante laureado,

rústico sin natural

y d'estudio y ciencia falto,

me dio impulso para hacer

1520 la relación que he contado

de su fiesta y de su templo,

aunque dicha en canto llano,

con voz ronca como cuervo

y con graznido de ganso.

1525 Pues, quien sabe que yo tengo

más faltas que aquí relato,

y que no me ha visto hacer

ningún verso bueno u malo,

y que he estado en su opinión

1530 en lo que soy, que soy asno,

sin duda dirá que es

aqueste mayor milagro.

Con esto dio fin la fiesta

1535 más buena para ser vista que no para escrita, Fabio.

¡Oh, qué cansado me deja!

¡Oh, qué cansado he quedado!

$1540 \quad$ cuatrocientos coplonazos.

$\mathrm{Y}$ hay alguno que me cuesta

más de cuatro malos ratos,

suspensiones más de seis

y paseos veinteicuatro,

1545 mordeduras de uñas muchas

y torceduras de manos,

que soy de aquellos poetas

que nos pinta en su Parnaso

Miguel Cervantes, que fueron

1550

movidos y zarandeados,

mendigos y pobretones

que hacen tres coplas al año.

$Y$ a lo menos esta vez

muy buena hartazga me he dado,

1548 Parnaso: alude al Viaje del Parnaso (1614) de Miguel de Cervantes, donde, entre otras cosas, se relata en estilo burlesco una batalla entre buenos y malos poetas. El autor de la Carta parece recordar pasajes concretos de la obra cervantina, como cuando se cuenta que Mercurio "zarandó mil poetas de gramalla" (II, v. 402), o donde se describe el escuadrón de los malos poetas como el "de la bárbara, ciega y pobre gente" (VI, v. 303). Véase Viaje del Parnaso, ed. Vicente Gaos, Castalia, Madrid, 1973. 
1555 mas no m'espanto, que ha mucho

que este género no masco.

Y esto viene a ser en mí

lo que en un músico malo,

que le ruegan por que cante

1560

y por que calle es rogado.

Relaciones llegarán

a esa villa upa el basto

de aquesta grandiosa fiesta,

que habrán escrito y cantado

1565 con estilo más subido

y conceptos muy delgados

las plumas de blancos cisnes,

ruiseñores y canarios.

Pero, ¿qué habemos de hacer?

$1570 \quad$ Ya echamos al toro el hato.

Suplid vos las faltas estas,

pues que sois mi amigo, Fabio;

que, como vos bien sabéis,

siempre canto como un pato

1575 y la pluma con que escribo

es pluma de gallinazo.

No hay otra cosa de nuevo

de que poder avisaros.

Las polleras son mayores

1580 y los moños ya son patos,

los perros muertos son muchos

1562 upa el basto: no queda claro el significado de este verso. Upa: "Esta sola palabra se dice levantando algún peso o levantándose persona pesada, como animando a que tomen esfuerzo" (Correas); basto: "Cierto género de aparejos o albardas que, a la moda extranjera, llevan las acémilas para la carga y para no lastimarse con ella" (Autoridades). Siguiendo estas acepciones, podría querer decir que 'las relaciones llegarán al Potosí por correo', transportadas en mulas 'sobre' ( upa) sus 'aparejos' (basto). Podría tratarse también de un término tomado del lenguaje de los naipes ('alza el basto'), pero el sentido del verso permanece oscuro.

1570 echar al toro el hato: variante de Echar la capa al toro: "Perder miedo y vergüenza, y dejar desierto y perdido algo" (Correas).

1576 gallinazo ('gallinaza'): 'zopilote'. Según Autoridades: “Ave que se cría en las Indias Occidentales, mayor que una gallina y menor que un pavo. Es muy negra y sirve de limpiar las calles de las inmundicias que en ellas se echan". En vez de ser un buen poeta ("cisnes, / ruiseñores y canarios"), el autor de la Carta se describe a sí mismo como un poetastro, comparándose con un ave carroñera americana. Es posible que haya una agudeza ulterior a partir de otra acepción de gallinaza: "El excremento o estiércol de las gallinas, del cual se valen los hortelanos para el beneficio de las huertas" (Autoridades).

1579 pollera: "Se llamaba el brial o guardapiés que las mujeres se ponían sobre el guardainfante, encima de la cual asentaba la basquiña o saya" (Autoridades).

1580 moño: "En las mujeres es especie de tocado o peinado, y por eso hacerse el moño vale peinarle" (Autoridades). Pero aquí hay una gracia a partir de otro significado de moño: "copete de pluma que tienen algunas aves" (Autoridades). Los moños de las damas limeñas son tan enormes (y vulgares) que no pueden compararse solo con una pluma, sino con un pato entero.

1581 perros muertos: véase el v. 1043. 
y los más se vuelven gatos,

y ahora esperan de España

el uso de renacuajos.

1585

Los hombres andan rellenos

con vestidos estofados,

ermitaños de cabello

y turcos en los mostachos.

Mucha pobreza había en Lima,

1590 pero ya se ha remediado,

que han puesto estanco de velas:

¡mirad si es bueno el reparo!

Otro para los poetas

ha de haber, que, desvelados,

1595 están meditando versos

y no amanecen con cuatro.

$\mathrm{Y}$, si ya se hubiera puesto, también yo hubiera comprado

para estas noches algunos

1600 que ha habido de claro en claro,

y a la mañana he salido

con tres coplas y enmendados

en ellas los nueve versos.

Y no malogré el trabajo,

1605

que otra noche subcedió

que, entregándome al cansancio

de este ejercicio local,

1582 gatos: juega con la doble acepción de 'animal doméstico' y ‘ladrón' (Autoridades), y está relacionado con gatazo: 'engaño, timo' (Alonso Hernández, Léxico, p. 396). El contraste jocoso entre perros y gatos sirve en este contexto para destacar la corrupción de Lima, donde los engaños (perros muertos) y los hurtos (gatos) abundan.

1584 renacuajos: no está claro este verso. Según Covarrubias, "Un muchacho mal tallado y enfadoso decimos que es un renacuajo”. Podría ser una burla de los señoritos venidos de España, o quizás tenga que ver con la indumentaria ridícula usada por los hombres en Lima, que los hace parecidos a renacuajos: sin cabello y con cola (bigotes largos). Véanse los vv. 1587-1588.

1586 estofado: de estofar: "Labrar a manera de bordado entre dos lienzos, hinchendo y rellenando de algodón o estopa el hueco o medio, y formando encima algunas labores, pespuntarlas y perfilarlas para que sobresalgan y hagan relieve" (Autoridades).

1587 ermitaños de cabello: con el cabello corto (o calvos) y los mostachos largos (turcos).

1591 estanco: "Se llama el asiento que se hace para acotar la venta de las mercancías y otros géneros vendibles, poniendo tasa y precio a que fijamente se hayan de vender, y embarazando que otros puedan tratar y contratar en los géneros que uno toma por su cuenta y por cuyos derechos y rentas hace escritura y obligación, como sucede en el tabaco, naipes, nieve y otras especies y géneros" (Autoridades). El monopolio de la venta de velas de sebo se estableció durante el gobierno del conde de Chinchón. En 1638 disfrutaban de la exclusividad en el abastecimiento de velas Lorenzo de los Ríos, Pedro de Navas, Pedro López de Lara y Sebastián de Valladolid (acerca de este último, véase el v. 993). Véanse Emilio Romero, Historia económica del Perú, Universo, Lima, 1968, t. 1, p. 258; Francisco Quiroz, Gremios, razas y libertad de industria: Lima colonial, Universidad Nacional Mayor de San Marcos, Lima, 1995, p. 128.

1594 desvelados: asociación ingeniosa entre vela y desvelado. Alude al frenesí creativo de los poetas, del que ya se hizo burla anteriormente (véase el v. 464). en Lima.

1607 ejercicio local: parece referirse a lo extendida que estaba la práctica de escribir versos 
me vi en él tan alcanzado que nunca pude coajar

1610 cuatro versos, aunque malos;

y, despechado, me dije:

"Conócete, hombre menguado, que no se hizo la miel para la boca del asno

$1615 y$ y, si pretendes hallarla, encontrarás con guarapo".

Breve se espera el aviso

de España, que en este año no le ha habido y está todo

1620 en suspensión y cuidado.

Muchas apuestas hay hechas a su llegada y hay varios pareceres cuándo sea. Yo también tengo apostado

1625 para el veinte deste mes veinte tercios de rosario; si los pierdo, no sé cómo los he de rezar ni cuándo, porque me faltan los dientes, $1630 \quad$ los de arriba y los de abajo, y se declaró en la apuesta que no han de ser meditados.

No acierto acabar la carta, que me veo encarnizado,

1635 como ha mucho que no tengo peleonas deste trato.

Pero al fin se ha de acabar, pero será a Dios rogando,

1640 Fabio, os conserve en salud muy felicísimos años.

Fecha en la ciudad de Lima y de agosto el día octavo, año de mil y seicientos y treinta y ocho empezados, que el cuerpo eterno del Padre, Cristo Jesús encarnado,

1616 guarapo: bebida alcohólica producida a partir de la caña de azúcar, como señala BERnABÉ Coвo: "guarapo, hecho de zumo de cañas dulces", Historia del Nuevo Mundo, ed. Marcos Jiménez de la Espada, Sociedad de Bibliófilos Andaluces, Sevilla, 1890-1893, t. 3, p. 35. Aquí parece indicar algo de baja calidad y sabor áspero, en contraste con la miel.

1617-1618 aviso de España: según Medrano, el correo oficial de España solía llegar "por el mes de mayo". Llevaba, pues, varios meses retrasado. Llegará el 18 de agosto de 1638: "llegaron a esta ciudad [Lima] los dichos cajones de pliegos de cartas de España" (SuARdo, Diario, t. 2, pp. 185 y 189).

1629 dientes: el poeta Menandro es mayor y no le quedan casi dientes en la boca, y, por lo tanto, no sabe cómo va a poder recitar en voz alta (y no meditados) los veinte tercios de rosario que ha apostado. 
nació para reparar

a todo el linaje humano.

Menandro, que ya desea

1650 más veros que no enviaros

relaciones tan insulsas

y tan desabridos platos.

Pienso, Fabio, estrañaréis

1655 La novedad no os admire, que poetas de mi trato me aconsejan que lo haga y su consejo he tomado, y así, de pastor moreno, 1660 me he vuelto pastor Menandro.

Laus Deo

\section{Aparato Crítico}

Epígrafe. edificación] dedificación con la d inicial tachada.

3. fiscal leal] fiscaleal

16. digo] di

37. el apóstol de las gentes] apóstol de las gentes. Añado el artículo para evitar que sea un verso hipométrico.

115. cuarenta] cuaren con ta añadido posteriormente.

183. que cinco] que todas cinco con todas tachado.

235. aquestos] aqestos

236. previenen] previene

260. que se hiciese] que hiciese

275. púlpito, altares, ventanas] púlpitos, altares, ventanas. En la iglesia solo hay un púlpito. La enmienda evita que el verso sea hipermétrico al establecer una sinalefa entre púlpito y altares.

363. agua] augua

364. dos] do

485. conoce] conce

556. ciriales] circeales

557. andas] anda

615. las suyas] lasuyas

635. estrellas] estrella

645. ángeles] ángel

651. andas] anda

657. querido] qerido

671. tan] ta

678. sotana y manteo] manteo y sotana

1659-1660 Acerca de estos versos, véase el apartado dedicado a la autoría del poema en la introducción. 
693. era] er

720. lucidos] lucido

773. dar] da

785. crucis] cricis

786. de un] de de un

800. cargaron] cargaban que enmiendo para evitar la falta de asonancia. Parece un error producido por la repetición del cargaban del verso 797.

822. adelante] adelanta

863. crucis] crisis

865. que en una custodia aquesto] que una custodia apuesto

888. los] lo

964. Ignacio] Ingnacio

1000. ocupado] ocupados

1001. fueran] fueron

1027. quebrar] quebra

1032. haberla] habela

1036. las] la

1043. mostrar] mostra

1111. todos] todo

1131. eficaz] ficaz

1146. candeladas] candelada

1208 agarrochados] agorrochados

1220. encarrujados] ecarrujados

1265. agustinos] agustino

1286. maesescuela] masescuela

1322. digno] disgno

1336. entonces] entonce

1366. cordel] corde

1408. concertados] comunes parcialmente tachado y corregido en concertados

1504. hurtado a algún] hurtado algún

1514. dichos] dicho

1528. verso] veso

1539. hecho] hechos

1570. toro] tor

1571. las faltas estas] las faltesta

1574. como] con

1599. algunos] algunas

1600. que ha habido] que habido

1615. pretendes] pretende

1619. le ha habido] le habido

1642. agosto] agosta

1651. insulsas] insultas que corrijo porinsulsas y no por incultas debido a que parece haber coherencia semántica con el verso siguiente: desabridos platos. 
